\title{
First record of Rhabdoceras suessi (Ammonoidea, Late Triassic) from the Transylvanian Triassic Series of the Eastern Carpathians (Romania) and a review of its biochronology, paleobiogeography and paleoecology
}

\author{
Eugen Grădinaru \\ Faculty of Geology and Geophysics, \\ University of Bucharest, Bucharest
}

\author{
Evgeny S. Sobolev \\ Siberian Branch of the Russian Academy of Sciences \\ Trofimuk Institute of Petroleum Geology and \\ Geophysics, Novosibirsk
}

\begin{abstract}
The occurrence of the heteromorphic ammonoid Rhabdoceras suessi Hauer, 1860, is recorded for the first time in the Upper Triassic limestone of the Timon-Ciungi olistolith in the Rarău Syncline, Eastern Carpathians. A single specimen of Rhabdoceras suessi co-occurs with Monotis (Monotis) salinaria that constrains its occurrence here to the Upper Norian (Sevatian 1). It is the only known heteromorphic ammonoid in the Upper Triassic of the Romanian Carpathians. Rhabdoceras suessi is a cosmopolitan species widely recorded in low and mid-paleolatitude faunas. It ranges from the Late Norian to the Rhaetian and is suitable for high-resolution worldwide correlations only when it co-occurs with shorter-ranging choristoceratids, monotid bivalves, or the hydrozoan Heterastridium. Formerly considered as the index fossil for the Upper Norian (Sevatian) Suessi Zone, by the latest 1970s this species lost its key biochronologic status among Late Triassic ammonoids, and it generated a controversy in the 1980s concerning the status of the Rhaetian stage. New stratigraphic data from North America and Europe in the subsequent decades resulted in a revised ammonoid biostratigraphy for the uppermost Triassic, the Rhaetian being reinstalled as the topmost stage in the current standard timescale of the Triassic. The geographic distribution of Rhabdoceras is compiled from published worldwide records, and its paleobiogeography and paleoecology are discussed.
\end{abstract}

Key words: Rhabdoceras suessi, Ammonoidea, Upper Triassic, Rarău Syncline, Transylvanian Triassic Series, Eastern Carpathians, biochronology, paleogeography, paleoecology.

Addresses: E. Grădinaru: RO-010041 Bucharest, Bd. Bǎlcescu Nicolae 1, Romania e-mail: egradin@geo.edu.ro E. S. Sobolev: RU-630090 Novosibirsk, Akademgorodok, Koptyug Ave., 3, Russian Federation, e-mail: essobolev@ngs.ru

Received: $\quad$ March 1, 2011; accepted: May 4, 2011 


\section{Introduction}

The ammonoid faunas of the Transylvanian Triassic carbonate rocks that made up an array of olistoliths embedded in the Lower Cretaceous Wildflysch Formation from the Rarău, Hăghimaş and Perşani Mts, and also build up a set of large klippen in the Perşani Mts, are referred to in numerous papers (e.g. Patrulius 1971; Patrulius 1996; Turculeț 1971 to 2005). However, no occurrence of Late Triassic heteromorphic ammonoids were recorded until now in the Transylvanian Triassic Series of the Eastern Carpathians.

While examining the fossils collected by the senior author in an old quarry in limestone of the Timon-Ciungi olistolith, the junior author, whose aim was to study the nautiloids, identified a fragment of a specimen of Rhabdoceras suessi Hauer, 1860, in the material. Consequently the purpose of the present paper is to describe this specimen, and to discuss the biostratigraphic range, chronostratigraphic relevance, and the paleobiogeographic distribution and paleoecology of this Late Triassic heteromorphic ammonoid.

\section{Geologic and stratigraphic settings}

The Timon-Ciungi olistolith, along with many other olistoliths composed of Triassic sedimentary and/or ophiolitic rocks, is embedded in Lower Cretaceous wildflysch that infills the Rarău Syncline of the Bucovinian Nappe in the northern part of the inner Eastern Carpathians (Săndulescu 1973). The Triassic rocks of the olistoliths and also of several large klippen scattered along the inner zone of the Eastern Carpathians, in the Rarău, Hăghimaş and Perşani Mts, are assigned to several, facially distinctive Transylvanian Triassic Series (Patrulius 1996).

The Timon-Ciungi olistolith is located on the left side of the drainage of the Timon Creek, which is a tributary of the Moldova River at the Fundu Moldovei locality (Fig. 1). The olistolith, several tens of meters in length, was largely quarried in the 1960s. The limestone quarry was abandoned for a long time and the area is now entirely reforested, with only few small exposures remaining. The main mass of the olistolith seems to be represented by thick-bedded light-grey limestone that is cut by Neptunian dykes filled with ammonoid-bearing, reddish nodular limestone. Monotis-bearing, Hallstatt-type reddish limestone occurs on the south-eastern side of the olistolith, its stratigraphic relationships within the olistolith being concealed by soil.

The cephalopod fauna and other fossil groups from the Upper Triassic limestone of the Timon-Ciungi olistolith were first investigated by Mutihac (1966, 1968), and have subsequently been extensively studied and described by Turculet (1971, 1976, 1980, 1983, 1986, 2000, 2003, 2004, 2005), Iordan $(1978,1993)$ and Popescu (2008).

The ammonoid fauna consists of more than fifty described taxa. Age-diagnostic taxa for the Middle Norian include Cyrtopleurites sp. ex. gr. C. socius Mojsisovics, 


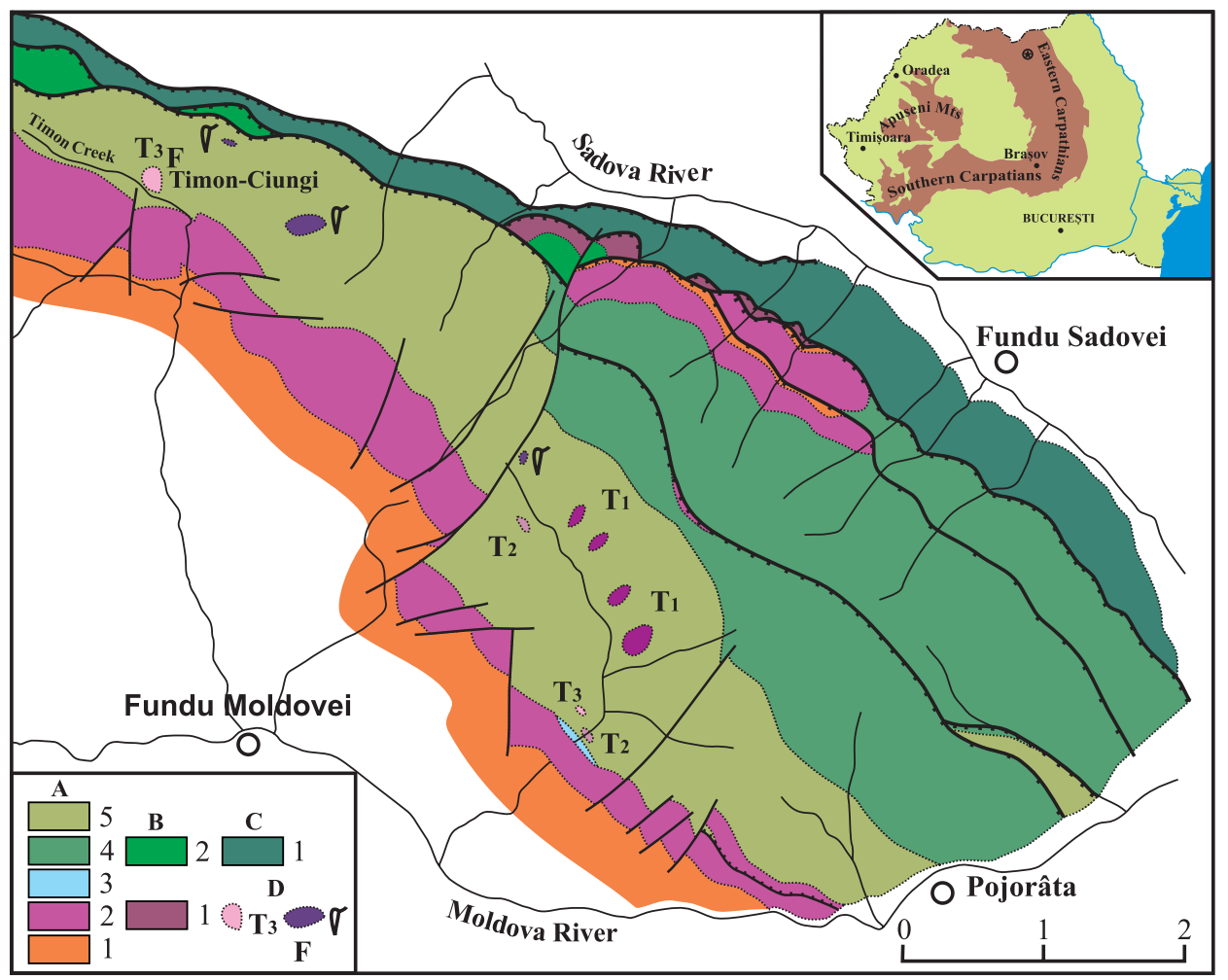

Fig. 1

Geologic map of the central part of the Rarău Syncline, Eastern Carpathians, Romania, with location of the Timon-Ciungi olistolith (modified from Săndulescu, 1973). Inset map shows the location (encircled star) of Timon-Ciungi olistolith in the Eastern Carpathians. A - Bucovinian Nappe: 1. PreAlpine basement; 2. Lower and Middle Triassic; 3. Middle Jurassic; 4. Tithonian-Neocomian; 5. Barremian-Albian - Wildflysch Formation. B - Subbucovinian Nappe: 1. Middle Triassic; 2. Neocomian; C - Ceahlău Nappe: 1. Tithonian-Neocomian. D - Triassic olistoliths: sedimentary and ultrabasic rocks. F - Fossil locality

Parathisbites sp. ex gr. P. meleagri Mojsisovics, Himavatites sp. aff. H. watsoni Diener, Halorites alexandri Mojsisovics, Halorites excentricus Turculeț, Halorites sp. ex gr. $H$. mitis (Mojsisovics); and for the Upper Norian to Lower Rhaetian, Megaphyllites insectus Mojsisovics, Placites polydactylus (Mojsisovics), Tragorhacoceras occultum (Mojsisovics), Stenarcestes sp. aff. subumbilicatus Hauer, Rhacophyllites invalidus Mojsisovics. The described ammonoid assemblage includes numerous other stratigraphically less useful species of leiostracan ammonoids, such as Placites, Arcestes, Cladiscites, Rhacophyllites and Megaphyllites, all of them have long ranges in the Norian-Rhaetian interval in the Hallstatt facies of the Northern Calcareous Alps (e.g. Krystyn 2008b). 
The lack of a precise ammonoid stratigraphic log hinders the establishment of an accurate biostratigraphy for the Timon-Ciungi olistolith. The published ammonoid fauna reflects a "rucksack-condensation", in the sense given to this term by Krystyn (2008b). However, taking into account the known ranges of the above mentioned age-diagnostic ammonoids, one can conclude that the Hallstatt-type limestone of the Timon-Ciungi olistolith spans a stratigraphic interval ranging from the Middle to Upper Norian (Sevatian 1), and higher into the Lower Rhaetian (Sevatian 2).

The specimen of Rhabdoceras suessi comes from Monotis-bearing reddish limestone. An orthocerid specimen of Trematoceras sp. is found on the same rock slab (Fig. 2). The monotid bivalves are assigned to Monotis (Monotis) salinaria (Schlotheim 1820) (Turculeț 2005).

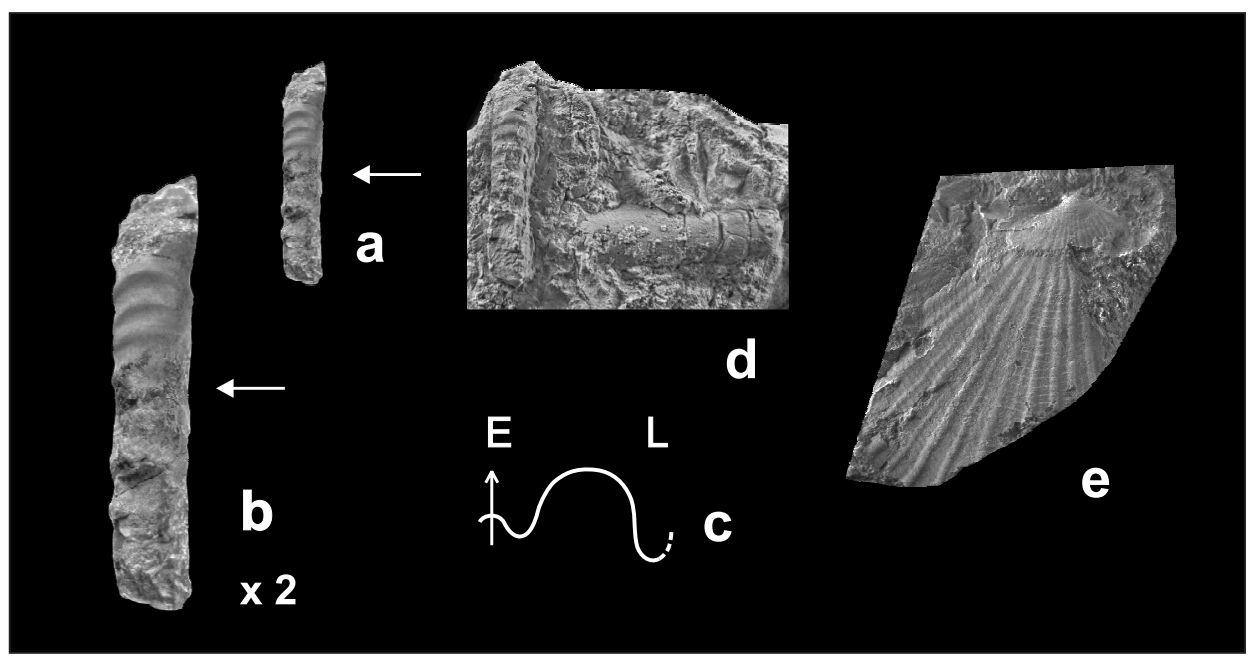

Fig. 2

a-b) Rhabdoceras suessi Hauer, ventral view: arrow indicates the last suture line; c) Suture line (part), $\times 6$; d) Rock sample with $R h$. suessi (left) and Trematoceras sp.; e) Monotis (Monotis) salinaria (Schlotheim), right valve; Specimens are figured at natural size, unless otherwise stated, and coated with ammonium chloride

The top-Norian occurrence and the pre-Rhaetian disappearance of the pectinoid bivalve M. (Monotis) salinaria, as documented in the Austrian Northern Calcareous Alps (McRoberts et al. 2008; Krystyn 2008b), allows determining a Late Norian (Sevatian 1) age for the occurrence of Rhabdoceras suessi in the TimonCiungi olistolith.

The Rhabdoceras suessi specimen found in the Hallstatt-type limestone of the Timon-Ciungi olistolith is the only record to date of a Late Triassic heteromorphic ammonoid in the Eastern Carpathians, as well as in the other Carpathian regions of Romania. 


\title{
Systematic paleontology
}

\author{
Class CEPHALOPODA CUVIER, 1797 \\ Subclass AMMONOIDEA ZITTEL, 1884 \\ Order CERATITIDA HYATT, 1884 \\ Suborder CERATITINA HYATT, 1884 \\ Superfamily CHORISTOCERATACEAE (HYATT 1900) TOZER 1979 \\ Family RHABDOCERATIDAE TOZER 1979 \\ Genus Rhabdoceras HAUER, 1860 \\ Type species: Rhabdoceras suessi HAUER, 1860 \\ Rhabdoceras suessi HAUER \\ (Text-fig. 2)
}

Rhabdoceras Suessi HAUER: Hauer 1860, p. 125, Pl. 2, figs 9-16; Mojsisovics 1893, p. 571, Pl. 133, figs 10-17; Gemmellaro 1904, p. 76, Pl. 18, figs 45-46; Arthaber 1906, Pl. 47, fig. 19a-b; Janensch 1906, p. 710, text-figs 1-2; Wanner 1910, p. 739; Jaworski 1915, p. 133, Pl. 45, figs 14-15; Diener 1915, pp. 247-248; Gemmellaro 1923, p. 138; Diener 1925, p. 93, Pl. 20, fig. 2; Kutassy 1927, p. 165, Pl. 6, fig. 8a-c.

Rhabdoceras suessi HAUER: Kutassy 1932, pp. 646-647; Kutassy 1936, p. 1041, Pl. 13, fig. 36; Muller and Ferguson 1939, p. 1605; Spath 1951, p. 86; Kummel 1957, p. 169, fig. 1997; Popov 1958, p. 43, Pl. 13, fig. 2; Tozer 1958, p. 15; Tozer 1963, Pl. 12, figs 18, 19a-c; Tozer 1965, p. 222; Kushlin 1965, p. 139, text-fig. 1a-d; Kushlin 1966, p. 844, text-fig. 1a-d; Zapfe 1965, p. 300, Pl. 1, fig. 8; Tozer 1967, pp. 38-40, 54, 55, 75, 77, 79-80, Pl. 10, figs 6, 7a-c; Sachariewa-Kowatschewa 1967, p. 76, Pl. 5, fig. 9; Tozer 1970, p. 634, Pl. 18, fig. 18a-b; Tozer 1971, p. 1020; Wiedmann 1972, p. 588, Pl. 3, fig. 3a-b; Urlichs 1972, pp. 668, 670; Krystyn 1973, pp. 131-132; Catalano et al. 1974, p. 1034; Wiedmann et al. 1979, p. 136, text-fig. 1a-b; Tozer 1979, p. 127, Pl. 16.1, figs 8-10; Kochanová and KollárováAndrusovová 1983, p. 577, Pl. 12, figs 3, 6, 7, 9; Krystyn 1987, pp. 23-25; Golebiowski 1988, p. 63; Tozer 1994a, p. 264, Pl. 144, figs 1-8, Pl. 147, figs 1-3, text-fig. 117c-g (p. 636), text-fig. 120i-j (p. 644).

Rhabdoceras (Rhabdoceras) suessi HAUER: Wiedmann 1973, p. 238, Pl. 1, figs 9a-c, text-fig. 1e; Shevyrev 1990, p. 137, Pl. 8, fig. 1; Shevyrev 2001, p. 144, text-fig. 23, Pl. 61, figs 6a-c; Shevyrev 2005, pp. 617-619, figs 3a-c, 4, 5.

Rhabdoceras suessi var. curvata MOJSISOVICS: Mojsisovics 1893, p. 572, Pl. 133, figs 13-14; Tozer 1979, p. 133; Kochanová and Kollárová-Andrusovová 1983, p. 578, Pl. 12, figs $1-2,4-5$.

Rhabdoceras (Cyrtorhabdoceras) curvatum MOJSISOVICS: Wiedmann 1973, p. 238, Pl. 1, figs 8a-b; Shevyrev 1990, p. 139, Pl. 8, figs 3-4; Shevyrev 2001, p. 145, Pl. 62, figs 1-2; Shevyrev 2005, p. 617, figs 3d-e.

Rhabdoceras russelli HYATT: Hyatt 1892, p. 398; Hyatt and Smith 1905, p. 203, Pl. 47, figs 13-15, Pl. 56, fig. 26; Smith 1927, p. 99, Pl. 47, figs 13-15, Pl. 56, fig. 26; Spath 1951, p. 86.

Rhabdoceras boreale AFITSKY: Afitsky 1965, p. 137, text-fig. 1; Afitsky 1970, p. 107, Pl. 3, fig. 1a-b. 
Rhabdoceras leave KUSHLIN: Kushlin 1965, p. 140, text-fig. 2a-d; Kochanová and Kollárová-Andrusovová 1983, p. 580, Pl. 12, figs 8, 10, Pl. 13, figs 1-16;

Rhabdoceras (Rhabdoceras) leave KUSHLIN: Shevyrev 1990, p. 138, Pl. 8, fig. 3; Shevyrev 2001, p. 145, Pl. 61, fig. 7a-c.

Rhabdoceras sp. ex gr. suessi HAUER: Geyer 1973, p. 24; Geyer 1979, p. 352.

Rhabdoceras cf. R. suessi HAUER: González-León et al. 2000, p. 493, figs 5, 8, 9, 10.

Rhabdoceras sp.: v. Hillebrandt 1994, p. 299, Pl. 1, fig. 17; Afitsky 1970, pp. 20, 26, 40;

Bychkov 2000, p. 105.

Rhabdoceras nov. sp.: Jaworski 1915, p. 135, Pl. 45, fig. 16a-b.

Material. One specimen (UBLG-GE 1065). The illustrated specimen is housed in the Laboratory of Geology, Faculty of Geology and Geophysics, University of Bucharest.

Dimension. Length of fragment $-22 \mathrm{~mm}$; height adapical $-4.6 \mathrm{~mm}$; width adapical $-4.2 \mathrm{~mm} ; \mathrm{h} / \mathrm{w}-0.91$.

Description. The single available specimen is a fragment of the straight part of the conch, one half representing the last part of the phragmocone and other the beginning of the body chamber. The ribbing is well preserved on the conch of the body chamber, and is projected ventrally, becoming stronger than on the flank, while on the dorsum it is weaker. The preserved portion of the body chamber is ornamented by six ribs. On the phragmocone, which is preserved as a steinkern, there are six visible suture lines showing a narrow and deep lateral lobe, a broad rounded marginal saddle and a shallow external lobe incised by a median saddle, that characterize the goniatitic suture lines of choristoceratids.

Discussion. The heteromorphic ammonoid Rhabdoceras is known commonly as fragmentary specimens, the initial coiled part, as described and illustrated by Janensch (1906), not even being found in the case of the large collections of Canadian material (Tozer 1994a). The rhabdoceratids commonly show variable morphologies, with straight and variable curved shells, showing also variable sculpture, from ribbed to virtually smooth. Morphologically different variants occur even in the same population, as emphasized by Tozer (1994a, p. 265), and it is also evident in the Slovakian and Pamirs materials (Kochanová and KollárováAndrusovová 1983; Kushlin 1966/1965; Shevyrev 1990, 2001). Several species of Rhabdoceras were described by different authors, as shown in the present synonymy, although there is no compelling evidence that these represent biochronologically distinct species. Wiedmann (1973) defined two distinct subgenera, Rhabdoceras (Rhabdoceras), with Rh. suessi Hauer, 1860, as the type species, and Rhabdoceras (Cyrtorhabdoceras), with Rh. suessi Hauer var. curvata Mojsisovics, 1893, as the type species. This typological taxonomy was followed by Shevyrev (1990, 2001, 2005). Kochanová and Kollárová-Andrusovová (1983) have not recognized the two subgenera of the genus Rhabdoceras, but they maintained the species oversplitting of the genus. In treating the taxonomy of the genus 
Rhabdoceras, a heteromorphic ammonoid that displays considerable variation in morphology and sculpture, we follow here the taxonomy adopted by Tozer (1994a). As the rhabdoceratids usually occur in fragmentary condition, in many cases it is not even possible to assign smaller pieces to straight or curved variants. Some geographically isolated rhabdoceratids, such as Rhabdoceras boreale which occurs along with specimens of Rhabdoceras sp. in Northeast Russia (Afitsky (1965/1966, 1970), despite showing slight differences in the suture line, are also included in the synonymy.

A separate case exists for Rhabdoceras curvatum Jaworski (Jaworski 1923, p. 153, Pl. 6, figs 1-2), not Rhabdoceras suessi Hauer var. curvata Mojsisovics, 1893, which was assigned to the genus Peripleurites by Geyer (1973, p. 24), then renamed as Choristoceras (Peripleurites) peruvianum by Wiedmann (1973, p. 239, Pl. 1, figs 6-7), and later considered as a representative of Rhabdoceras, i.e. Rh. peruvianum, by Krystyn (1990, p. 20). It is placed by Tozer (1994a, p. 265) in the synonymy of Peripleurites roemeri Mojsisovics, 1893.

Occurrence. The heteromorphic ammonoid Rhabdoceras suessi had a very broad geographic distribution during the Late Triassic in low and middle latitudes both in the Northern and Southern Hemispheres. In western North America, Rh. suessi is well documented from the Cordilleranus, Amoenum and Crickmay Zones, occurring in some localities in sequence within all zones, such as in British Columbia in western Canada. Along the Alpine-Himalayan-Indonesian orogenic belt, Rh. suessi occurs from Alpine Europe to the Pamirs, and further on to southeast Indonesia, being known together with age-diagnostic choristoceratids from all Upper Norian and Rhaetian biozones.

\section{Biostratigraphic range and chronostratigraphic relevance}

For a long time, the use of the heteromorphic ammonoid Rhabdoceras suessi for the chronostratigraphy of the uppermost Triassic was closely related to the progressive knowledge increase of the biostratigraphic ranges of Late Triassic ammonoids in general, and of the aforementioned heteromorphic ammonoid in particular. This in turn deeply influenced the evolution of ammonoid zonal concepts and their impact on the definition of the Norian-Rhaetian boundary, as well as on establishing the chronostratigraphic status of the Rhaetian, respectively.

Biostratigraphic range. Rhabdoceras suessi is now known to be a long-ranging heteromorphic ammonoid spanning almost the whole interval of the Upper Norian (Sevatian 1) to Rhaetian (Fig. 3). However, it was not known as such until the latest 1970s.

Before the latest 1970s. The Northern Calcareous Alps in Austria represents the homeland of the Late Triassic heteromorphic ammonoid Rhabdoceras suessi. From here Hauer (1860) first described and presented data on the occurrence of 


\begin{tabular}{|c|c|c|c|c|c|}
\hline \multicolumn{4}{|r|}{ TETHYS } & NORTH AMERICA & \multirow{2}{*}{$\begin{array}{l}\text { Rhabdoceras suessi and } \\
\text { Monotis salinaria } \\
\text { stratigraphic range }\end{array}$} \\
\hline \multicolumn{3}{|c|}{ Stage } & ZONE & ZONE & \\
\hline \multirow{3}{*}{ 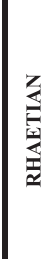 } & \multicolumn{2}{|c|}{ upper } & Choristoceras marshi & \multirow{2}{*}{ Choristoceras crickmayi } & \multirow{4}{*}{$\begin{array}{l}\text { Rhabdoceras } \\
\text { suessi } \\
\qquad \begin{array}{l}\text { Monotis } \\
\text { salinaria }\end{array}\end{array}$} \\
\hline & \multicolumn{2}{|c|}{ middle } & Vandaites stuerzenbaumi & & \\
\hline & 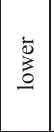 & 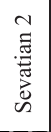 & $\begin{array}{l}\text { Sagenites reticulatus } \\
\text { (Paracochloceras suessi) }\end{array}$ & Paracochloceras amoenum & \\
\hline \multirow{4}{*}{ 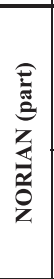 } & $\begin{array}{l}\overline{\mathrm{o}} \\
\stackrel{2}{\Xi}\end{array}$ & 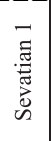 & $\begin{array}{l}\text { Sagenites quinquepunctatus } \\
\text { (Metasibirites spinescens) }\end{array}$ & Gnomohalorites cordilleranus & \\
\hline & \multirow{3}{*}{$\frac{\mathscr{\varrho}}{\tilde{g}}$} & \multirow{3}{*}{ 胥 } & Halorites macer & \multirow{2}{*}{ Mesohimavatites columbianus } & \\
\hline & & & $\begin{array}{l}\text { Himavatites hogarti } \\
\text { Himavatites watsoni }\end{array}$ & & \\
\hline & & & Cyrtopleurites bicrenatus & Drepanites rutherfordi & \\
\hline
\end{tabular}

Fig. 3

Late Triassic ammonoid zonation and stratigraphic ranges of Rhabdoceras suessi Hauer 1860, and $M$. (Monotis) salinaria (Schlotheim 1820). Ammonoid zonation adopted from Krystyn et al. (2007a-b), Krystyn (2008a-b), Krystyn et al. (2009) for Tethyan Europe, and from Tozer (1980b-c, 1982a-b, 1984, 1994a-b), and Orchard and Tozer (1997) for North America

Rhabdoceras suessi in the Hallstatt limestone. Afterwards, Mojsisovics (1893) reported the occurrence of Rhabdoceras suessi in various facies of Hallstatt limestone assigned to the so-called "Juvavische Stufe" (= Norian Stage; see Tozer 1965, p. 223) and also from the "Cochloceras" beds in the Zlambach Formation. In the Hallstatt limestone Rhabdoceras suessi was recorded from the Sagenites giebeli and Cladiscites ruber Zones, as well as from the Pinacoceras metternichi Zone, which in Mojsisovics's (1902) zonal scheme were assigned to the "Lower Juvavic" (Lacian) and "Upper Juvavic" (Sevatian) Substages, respectively. As later proved by Krystyn et al. (1971), the ammonoid assemblages in the "Hangendrotkalk" facies of the Hallstatt Limestone, such as those of the Gastropod Beds of Millibrunnkogel (Cladiscites ruber Zone), and from Leislingwand (Sagenites giebeli Zone) and Ferdinandstollen (Glyphidites docens lens), had been wrongly emplaced by Mojsisovics (1902) into the "Lower Juvavic" (Lacian).

Kittl (1903) provided the first exact known data on the stratigraphic occurrences of Rhabdoceras suessi in the Hallstatt limestone occurrences of the Salzkammergut region (at Siriuskogel, in the "Pinacoceras metternichi Zone" together with "Cochloceras" amoenum and Monotis salinaria; at Taubenstein, together with Sagenites quinquepunctatus; at Steinbergkogel near Hallstatt and "Franzberg", together with "Cochloceras", Pinacoceras metternichi, galeate Arcestidae and Heterastridium) and also in the Zlambach Formation (at Stambachgraben near Goisern, in the Cochloceras-beds). In Kittl's (1903, p. 16, tab. 2) stratigraphic scheme of the Triassic from the Salzkammergut region, the ammonoid faunas of the 
"Pinacoceras metternichi Zone" and of the "Cochloceras"-beds are assigned to the Upper Norian. Arthaber (1904, pp. 382, 385) reaffirmed the Upper Norian (Sevatian) age for the "Metternichi-Kalke der Hallstätter Facies" and for the "Cochloceras-Bänke der Zlambach-Facies".

Following the glorious period of the second half of the 19th century, when studies of the Triassic ammonoids were initiated and extensively developed by the famous "Geologic School of Vienna", a gap of more than five decades elapsed, when studies of the Tethyan Triassic ammonoids were only occasionally carried out in Europe. The studies of Alpine Triassic ammonoids resumed in the early 1960s and mostly extended into the 1970s in Austria and a few other European countries.

In Italy, Gemmellaro (1904, 1923) and Catalano et al. (1974) reported the occurrence of Rhabdoceras suessi together with Heterastridium conglobatum (Hauer) from the Upper Norian limestone in the Palermo region of Sicily.

In Hungary, Kutassy $(1927,1936)$ mentioned the occurrence of Rhabdoceras suessi in the Norian Dachstein-type limestone.

In Austria, Zapfe $(1962,1965,1967 a)$ found Rhabdoceras suessi in the DachsteinRiffkalk of the Gosaukamm in the Dachstein Mts. Krystyn (1973, p. 132) reported the occurrence of Rhabdoceras suessi in the Upper Norian (Sevatian) from the Suessi Zone (sensu Tozer 1967), and in support of this the author referred to the ammonoid faunas described by Mojsisovics from the Hangendrotkalk and Hangengraukalk facies of the Hallstatt Limestone, and also from the Zlambach Beds in the Salzkammergut region. Wiedmann (1972) found Rhabdoceras suessi in the Zlambach Marls, and on this basis the author assigned the "Bereich III-IV" to the Suessi Zone (sensu Tozer 1967), regardless of his several available options for the position of the Norian-Rhaetian boundary.

In the Balkans, Sachariewa-Kowatschewa (1967) described Rhabdoceras suessi in an ammonoid assemblage including several species of Metasibirites (M. spinescens, M. uhligi, M. crassus, etc.), and Cochloceras fischeri, together with other longranging ammonoids that in the standard zonation of the time were assigned to the Upper Norian.

Outside of Alpine Europe, the occurrence of Rhabdoceras suessi was mentioned by Wanner (1910) and Jaworski (1915) in the Upper Norian Nucula-Mergel from the Misool Archipelago of Indonesia, occurring together with different species of Cochloceras and Paracochloceras. Tozer (1971, p. 1020) reported the occurrence of Rhabdoceras suessi at Aliambata in Timor-Leste (East Timor) in a Late Norian ammonoid assemblage including Glyphidites docens and other age-diagnostic ammonoid genera. From Central Asia, Kushlin (1965) described Rhabdoceras suessi from the Norian of the southeast Pamirs, without any other specification on its exact stratigraphic occurrence.

In the Western Hemisphere, the occurrences of Rhabdoceras suessi were recorded in the United States in the first half of 20th century by Hyatt and Smith in their classical studies on Triassic ammonoids. Later, more data on the 
stratigraphic occurrence of this heteromorphic ammonoid were provided by collections made by S.W. Muller of Stanford University in 1930s-60s, and starting in the early 1950s, by the studies of E.T. Tozer in Canada and those by N.J. Silberling in the United States.

In the United States, Rhabdoceras russelli was described by Hyatt (1892) from the Taylorsville area in northern California, and reported in California and Nevada by Smith (1927) from the Norian Pseudomonotis subcircularis Zone [this monotid species is now referred to the genus Monotis (Pacimonotis)], and was considered a junior synonym of Rhabdoceras suessi by Tozer (1967, p. 39; 1994a, p. 265). Later, the occurrence of Rhabdoceras suessi was reported by Muller and Ferguson (1939, p. 1605, tab. 4) in the Gabbs Formation in Nevada from the upper part of the Upper Norian Suessi Zone, as revised by Silberling and Tozer (1968, p. 32). Silberling and Tozer (1968) reported occurrences of Rhabdoceras suessi at a number of localities in western Nevada, and also in northern California, occurring together with Metasibirites spinescens (Hauer), Monotis subcircularis, Monotis cf. M. salinaria and the hydrozoan Heterastridium.

In Canada, Tozer $(1958,1965)$ found that Rhabdoceras suessi occurs both in and above the beds with Monotis subcircularis (Gabb) in the Yukon Territory, British Columbia and Vancouver Island. Tozer (1965, p. 224) mentioned that at Tyaughton Creek, southern British Columbia, strata with Rhabdoceras are overlain by beds with Choristoceras cf. C. marshi Hauer (now Choristoceras crickmayi, Tozer 1979), the latter assumed to be correlative with the Kössen Beds of the northern Alps. Taking into account that the Kössen Beds were at that time considered the standard for the uppermost Triassic Rhaetian Stage and these were regarded as younger than the Norian in the European Triassic chronostratigraphic scheme, Tozer (1965, p. 225) concluded that all above-mentioned occurrences suggest that in Canada Rhabdoceras suessi is restricted to the Upper Norian. On the basis of the data from the Canadian Norian ammonoid sequence, Tozer (1965, pp. 224-225; 1971, p. 1020) was also able to demonstrate that the two Salzkammergut zones of Sagenites giebeli and Cladiscites ruber regarded by Mojsisovics (1902) as Lower Norian and where the occurrence of Rhabdoceras suessi was reported, are essentially correlative with the Upper Norian Pinacoceras metternichi Zone. Moreover, the occurrences of Monotis in the Salzkammergut evidently support an approximate correlation with the North American Monotis subcircularis Zone. Thus, based on the available data, Tozer (1965) found no apparent conflict in the revised Mojsisovics's Alpine Norian ammonoid sequence and the occurrences of Rhabdoceras suessi in Canada. Subsequently, Schlager (1969, p. 293) and Krystyn et al. (1971, pp. 286-288) provided field evidence in support of Tozer's Canadian findings, demonstrating that Mojsisovics's Norian ammonoid zonal sequence does not represent a normal sequence, being based on more or less isolated occurrences of ammonoid faunas supposedly arranged in a zonal scheme.

On the basis of the ammonoid succession in North America, Tozer (1967, p. 40; 1971, p. 1020) and Silberling and Tozer (1968, p. 16) emphasized that the North 
American Suessi Zone newly named by them, with Rhabdoceras suessi as the nominal index fossil and stratotype in Nevada, may be correlated with the Pinacoceras metternichi Zone of Austria, as represented in the Hallstatt Limestone of the Steinbergkogel, and with the Cochloceras-bearing part of the Zlambach Beds, as exposed in the Stambachgraben. Rhabdoceras suessi is reported in North America from both 'Lower Suessi Zone", equivalent to the Monotis subcircularis Zone, and the "Upper Suessi Zone", which includes the Norian beds that overlie Monotis subcircularis (referred to as the Supramonotis Beds). Since an adequate boundary between the lower and upper parts of the Suessi Zone cannot yet be defined, it is stressed by Silberling and Tozer (1968, p. 33) that Rhabdoceras suessi and some other long-range ammonoid species appear to range through most or all of the zone, but species of Cochloceras (or Paracochloceras) and Cycloceltites may be restricted to its upper part. Since this pattern in the faunal sequence inside the North American Suessi Zone was also known long before by Kittl (1903) in the Austrian Alps, it is relevant because it concerns the further evolution in chronostratigraphic nomenclature and concepts of the Norian-Rhaetian boundary (this question will be dealt with later). It bears the biostratigraphic premise for splitting the classical Sevatian Substage into two distinct parts and to equate the Sevatian 2, characterized by the occurrence of Cochloceras (or Paracochloceras), with the lower part of the Rhaetian as it is actually defined by Krystyn et al. (2007a-b).

To summarize the data of this period, in terms of the chronostratigraphic nomenclature applied to the North American zonal sequence, as promoted by Tozer $(1967,1970,1971,1974)$, which was also adopted in Europe by Krystyn (1973, 1974, 1980), Zapfe (1974), Tollmann (1976) and Wiedmann et al. (1979), the occurrence of Rhabdoceras suessi was customarily confined to the Upper Norian (Sevatian) Suessi Zone, that in most chronostratigraphic schemes underlies the Rhaetian Marshi Zone (Fig.4).

The latest 1970s and onwards. In the Northern Calcareous Alps, Urlichs (1972) and Möstler et al. (1978) stated that the beds with Rhabdoceras suessi underlie those with Choristoceras marshi in the Kössen Beds, and consequently they assigned the beds with Rhabdoceras suessi to the Upper Norian and those with Choristoceras marshi to the Rhaetian. In the first instance, the Kössen data were promptly taken by Tozer (1974, pp. 203-204) to justify the North American SuessiMarshi zonal scheme. However, the finding of Rhabdoceras suessi in the lower part of the Kössen Beds, traditionally considered as the stratotype for the classical Rhaetian, represented for Tozer $(1971,1974)$ the turning point from which he began to doubt the validity of the Rhaetian as a valid chronostratigraphic unit for the uppermost Triassic, by advancing the idea that the Sevatian and Rhaetian overlap in their scope.

New data on the ammonoid succession in Canada provided by Tozer (1979, 1980b-c, 1984), later fully developed by Tozer (1994a) in his excellent monograph on the Canadian Triassic ammonoid faunas, shed a completely different, new 
light on the biostratigraphic range of Rhabdoceras suessi. Tozer found that Rhabdoceras suessi is present in all of the new three zones he defined for the uppermost part of the North American Triassic, the Gnomohalorites cordilleranus, Cochloceras amoenum and Choristoceras crickmayi Zones, in ascending order. Compared with the previous North American scheme, the first two zones replace the two informal divisions of the Upper Norian Suessi Zone, while the Crickmayi Zone replaces the Rhaetian Marshi Zone. Tozer classified all three newly-named zones as Upper Norian (Sevatian) and argued against the Rhaetian as a valid chronostratigraphic unit, an opinion that has caused considerable controversy in the following years (this question will be dealt with later). Based on the new data, which proved a more extended biostratigraphic range for Rhabdoceras suessi in North America than was known before, Tozer concluded that the former Suessi Zone serves no purpose in the chronostratigraphic subdivision of the uppermost Triassic, and extended the Upper Norian (Sevatian) to the top of the Triassic (Fig. 5 , columns 1 and 2).

The subsequent data obtained in the Northern Calcareous Alps also confirmed the more extended biostratigraphic range of Rhabdoceras suessi in the uppermost part of the Triassic. These data came not from the Hallstatt Limestone but from the time-equivalent Kössen and Zlambach beds. Wiedmann et al. (1979) reported that Choristoceras marshi - an index fossil of the restricted Rhaetian - was found in the lower part of the Kössen Beds of the Lahnewiesgraben, equivalent to the former Rhabdoceras suessi Zone. Upon this discovery Wiedmann et al. (1979, p. 142, tab. 2) made four proposals for defining the Alpine uppermost Triassic chronostratigraphy, none of them being later validated. Golebiowski (1986, figs 3-4) reported that in the Kössen Beds the occurrence of Rhabdoceras suessi reaches up into the lower part of the Marshi Zone, where it co-occurs with Choristoceras ammonitiforme, underlying the beds with Ch. marshi. A similar ammonoid sequence was also found by Krystyn (1988) in the Zlambach Marls. On the basis of a new, detailed ammonoid sequence defined in the Zlambach Marls, Krystyn (1988, p. 24, fig. 1) developed a new, shorter concept for the Rhaetian, as the ultimate stage of the Triassic (Fig. 5, column 4). By adopting Krystyn's new ammonoid zonal scheme for the Zlambach Beds, Golebiowski (1990, fig. 1) restricted the occurrence of Rhabdoceras suessi to the Rhaetian section of the Kössen Formation, i.e. in the Vandaites stuerzenbaumi Zone and to the lower part of the Choristoceras marshi Zone, respectively. Although Krystyn (1990, p. 15) had earlier claimed that the Cochloceras fauna "for a long time served as the topmost Norian ammonoid standard and would remain in this position in the future too", subsequent new detailed data on the ammonoid biostratigraphy from the Hallstatt Limestone at Steinbergkogel demonstrated that the Paracochloceras/ Cochloceras fauna is chronostratigraphically equivalent to the Lower Rhaetian Sagenites reticulatus Zone (Krystyn and Kuerschner 2005, fig. 1, p. 18; Krystyn et al. 2007a-b). Hence, a new definition for a larger Rhaetian Stage was proposed, with the Paracochloceras suessi Zone, equivalent of the North American 
Paracochloceras amoenum Zone, as its basal ammonoid zone (Fig. 5, column 5). In this case, the Sevatian 2 becomes the Lower Rhaetian, in opposition with the former usage of the Sevatian 1 and 2 as lower and upper substages for the Upper Norian, having as index fossils Sagenites quinquepunctatus and Sagenites reticulatus and/or Paracochloceras suessi, respectively (Gallet et al. 1996, 2003, 2007).

As a consequence of the new detailed ammonoid zonal sequence in the Hallstatt basin of the Northern Calcareous Alps, objective data demonstrate that the biostratigraphic range of Rhabdoceras suessi extends, as in North America, to include almost the entire interval of the newly-defined Upper Norian (=Sevatian 1) Substage and the Rhaetian Stage (Krystyn 2008b; Maslo 2008), and that this ammonoid represents a less-time diagnostic choristoceratid.

The other reported occurrences of Rhabdoceras suessi throughout the world are also proving that the stratigraphic range of this heteromorphic choristoceratid spans the whole interval of the Upper Norian to Rhaetian.

In the Slovakian Carpathians, Kollárová-Andrusovová (1983) and Kochanová and Kollárová-Andrusovová (1983) mentioned the occurrence of Rhabdoceras suessi in the Sevatian Hallstatt limestone.

In the southeast Pamirs Shevyrev (1990, p. 98; 2001, pp. 144-145) reported Rhabdoceras suessi together with other long-range ammonoids, along with Monotis salinaria and Heterastridium conglobatum, that are assigned to the Sagenites quinquepunctatus Subzone in the Suessi Zone. This subzone was initially regarded by Shevyrev (1990, tab. 12, p. 94) as equivalent to the Lower Rhaetian, where the Rhaetian Stage (sensu Wiedmann et al. 1979, p. 145) includes both the Suessi and Marshi Zones. Later, the ammonoid assemblage of the Sagenites quinquepunctatus Subzone in the Pamirs was regarded as Upper Norian (Dronov 2001, p. 12, tab. 2).

On the Alaska Peninsula, Pálfy et al. (1999) mentioned the occurrence of Rhabdoceras together with Metasibirites, Monotis and Heterastridium from the Upper Norian.

In South America, Geyer $(1973,1979)$ reported the occurrence in Columbia of Rhabdoceras sp. ex gr. suessi, together with Metasibirites spp. and Monotis subcircularis in the Upper Norian, while Hillebrandt (1994, p. 299, fig. 2) recorded the occurrence in Peru of Rhabdoceras sp. in the Lower Rhaetian Suessi Zone (sensu Wiedmann et al. 1979, p. 145).

In Mexico, González-León et al. (2000) found Rhabdoceras cf. R. suessi together with Choristoceras cf. C. nobile Mojsisovics, and interpreted them as indicative for the uppermost Triassic Crickmayi Zone.

To summarize the data of this period, and taking into account the most recent Alpine chronostratigraphic scheme for the uppermost Triassic, with a new definition of the Norian-Rhaetian boundary, it is now known that Rhabdoceras suessi Hauer is a long-ranging heteromorphic ammonoid covering the entire interval of the newly defined Upper Norian (=Sevatian 1) Substage and the Rhaetian Stage (Fig. 3). 
However, despite the fact that Rhabdoceras suessi has lost its quality as a zonal index species, the main result of the newly acquired data is that this long-ranging choristoceratid can contribute to dating and high-resolution correlation of uppermost Triassic strata only in co-occurrence with short-range, biostratigraphically diagnostic choristoceratids or with monotid bivalves and the hydrozoan Heterastridium.

Chronostratigraphic relevance. As far as its relevance for the Upper Triassic chronostratigraphy is concerned the heteromorphic ammonoid Rhabdoceras suessi Hauer experienced a period of celebrity during the 1970s, when it had the status of a zonal index species, but fell into the shadows by the latest 1970s, when it lost this status. This change in its chronostratigraphic relevance was the direct consequence of newly-gained knowledge of the true biostratigraphic range of Late Triassic ammonoids in general, and of this heteromorphic ammonoid in particular.

In the 1970s, Rhabdoceras suessi Hauer was designated by Tozer (1967) and Silberling and Tozer (1968) as an index fossil for the Upper Norian (Sevatian) Suessi Zone (= Rhabdoceras suessi Zone), underlying the Rhaetian Marshi Zone (= Choristoceras marshi Zone) in the standard Triassic time scale for North America, and this stratigraphic scheme was also adopted for the uppermost Triassic in the Alpine Europe (Fig. 4).

As subsequently demonstrated in the 1980s, the designation of Rhabdoceras suessi as an index fossil for the Upper Norian Substage in fact reflected an as yet poor knowledge at that time of the ammonoid succession in the uppermost part of the Triassic, both in North America and in Alpine Europe.

Starting with the latest 1970s and mostly in the 1980s, Tozer $(1979,1980 \mathrm{~b}-\mathrm{c}$, 1984) introduced a new ammonoid zonal scheme for the North American uppermost Triassic based on a detailed time-diagnostic ammonoid biostratigraphy in a stratigraphically well-ordered sequence. Tozer also changed the former chronostratigraphic nomenclature of the uppermost Triassic, as used for the European Alpine Triassic timescale, by extending the Norian Stage to the top of the Triassic, and questioned the status of the Rhaetian as a stage at the top of the Triassic (Fig. 5, columns 1, 2 and 1-2). From this Tozer (1980b, p. 413) concluded that the "Upper Norian", "Sevatian" and "Rhaetian" should be treated as synonymous substages. Even in the early 1970s, Tozer (1971, p. 1020) questioned the status of the Rhaetian, when he claimed that "in terms of ammonoid faunas it is difficult to justify recognizing a Rhaetian Stage". In support of his early opinion, Tozer recalled an inference made by Zapfe (1967a, p. 13), who found that a genuine similarity exists between the Upper Norian "Sevatic" and Rhaetic (?Lower Rhaetic) ammonoid faunas of northern Alps. However, it must be emphasized that Zapfe $(1967$, p. 13) had not questioned in any case the status of the Rhaetian Stage; on the contrary, he merely underlined "it is probable that we shall have to revise the biostratigraphic range of some Upper Triassic index fossils and even of whole index faunas". 


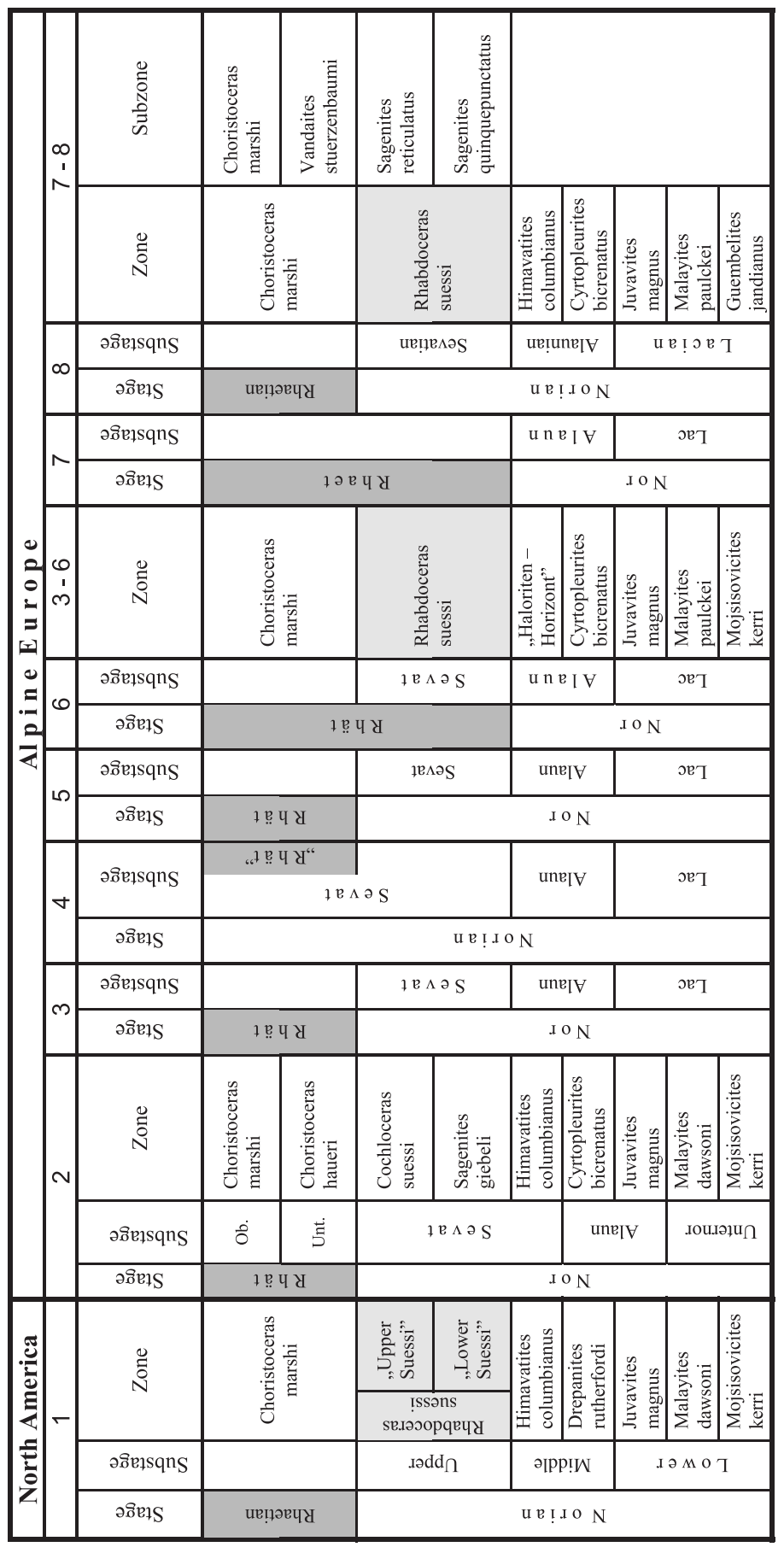

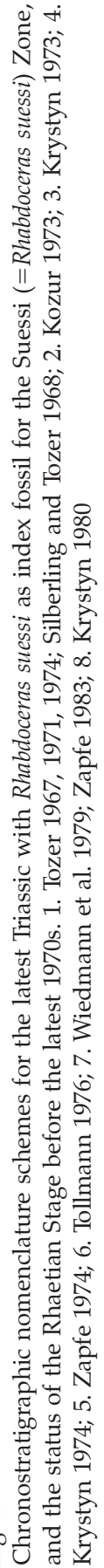

Central European Geology 53, 2010 
Tozer's rejection of the Rhaetian Stage opened a vigorous debate on the subject in the 1980s. It is what was called "The Rhaetian Controversy: 1978-1988" in Albertiana, 6 (1987, p. 13).

It is not the purpose here to discuss in detail the history of the Rhaetian as a stage and the evolution of concepts for the definition of the Norian-Rhaetian boundary. On this subject the reader is referred to the papers by Pearson (1970), Tozer (1971, 1980b-c, 1984, 1986, 1988, 1990, 1993; 1994b), Wiedmann (1972), Kozur (1973), Wiedmann et al. (1979), Gazdzicki et al. (1979), Krystyn and Wiedmann (1986), Krystyn (1988, 1990, 2008b), Dagys and Dagys (1994), Krystyn and Kuerschner (2005), Krystyn et al. (2007a-b).

What must be emphasized from the beginning is that it was only the finding of the real biostratigraphic range of the heteromorphic ammonoid Rhabdoceras suessi in the North American Upper Triassic, of a greater extent than was known before, that prompted Tozer (1979) not only to eliminate the Suessi Zone as the timeequivalent for the Upper Norian Stage but also to question the value of the Rhaetian as a valid time-stratigraphic subdivision in the uppermost Triassic. Also, we shall emphasize that Tozer's rejection of Gümbel's Rhaetian received justified support because of the lack of a proper definition and of a valid stratotype for it in the European Alpine Triassic on the one hand, and due to the absence of a detailed ammonoid biostratigraphy for the Alpine uppermost Triassic on the other. All these enabled an unstable and confusing stratigraphic nomenclature for the European Alpine uppermost Triassic until the early 1980s, in contrast with new achievements in the North American Triassic stratigraphy.

In reply to Tozer's opinion, at the conference of the Subcommission on Triassic Stratigraphy, held in Munich in July of 1978, a resolution was adopted concerning about the stratigraphic status of the Rhaetian. The Subcommission made the following recommendations: 1 ) the name Rhaetian should be applied exclusively to strict chronostratigraphic meaning, and 2) the term Rhaetian sensu Gümbel should be preserved and should be used as the denotation of the uppermost Stage of the Triassic System, i.e. including or representing the Sevatian or Upper Norian, respectively.

During the 1980s, Albertiana, the journal of the Subcommission on Triassic Stratigraphy, hosted a vigorous debate around the status of the Rhaetian among the North American Triassic workers (Tozer 1986, 1988, 1990; Silberling and Nichols 1988) on one side, and the European Triassic workers (Ager 1987, 1988, 1990; Dagys 1988; Krystyn 1990; Golebiowski 1990) on the other.

Ager $(1987,1990)$ defended the Rhaetian as the final stage of the Triassic, contrary to Tozer $(1980,1988,1990)$ and Silberling and Nichols (1988), although unfortunately Ager referred to the Kössen Beds as the stratotype for the Rhaetian and thus directed the first discussions on the status of the Rhaetian in the wrong direction.

In his reply to Ager's (1988) defense of the Rhaetian in terms of the Kössen Beds, Tozer (1988), with good reason in this instance, classified the Rhaetian as "a 
First record of Rhabdoceras suessi (Ammonoidea) from the Transylvanian Triassic Series 277

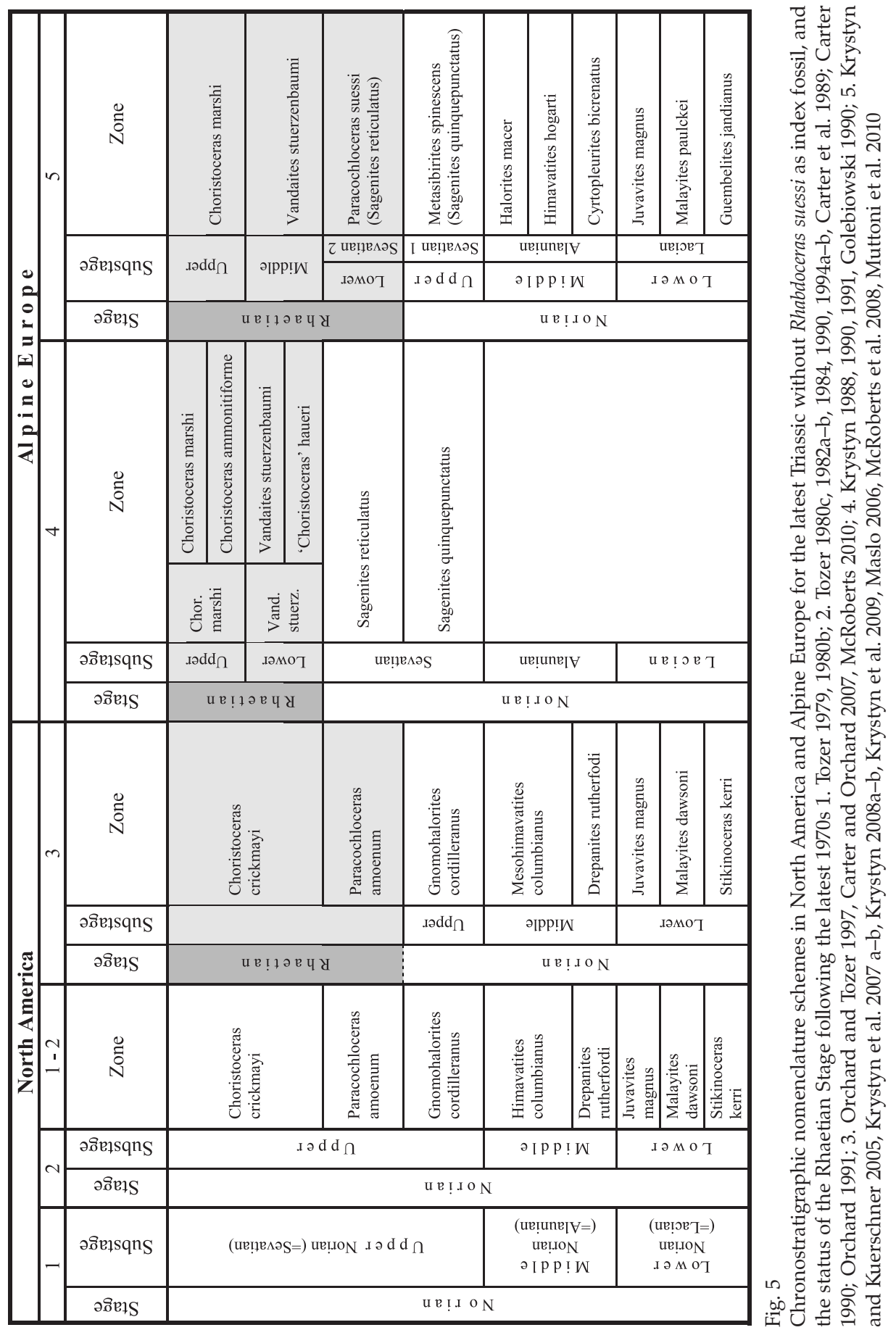

Central European Geology 53, 2010 
two-faced creature", i.e. a Rhaetian sensu lato classically defined in terms of the Alpine Kössen stratotype, and a Rhaetian sensu stricto that is chronostratigraphically defined by the Choristoceras marshi Zone (sensu Tozer 1974, p. 203), which is the upper part of the Kössen. It is quite surprising to see that Tozer (1986, 1980b, 1988, 1990), in his dispute on the Rhaetian, obsessively referred to the Kössen Beds as the standard of the classical Rhaetian, as it was defined by Gümbel in 1859. Although even he insisted repeatedly that the time-stratigraphic units, of which the stage is the fundamental category, are based on ammonoid zones, and these should be defined by their basal boundary in a stratotype, Tozer a priori rejected the Rhaetian as a distinct stage, instead of calling for a valid stratotype for it in the European Alpine Triassic. Furthermore, when Urlichs (1972) found that Rhabdoceras suessi, then the nominal index fossil for the Upper Norian (Sevatian s.l.), occurs in the lower part of the Kössen Beds, Tozer claimed that the Sevatian and the classical Rhaetian overlap more or less in their scope in the Alpine Kössen stratotype, by sharing common ammonoid faunas. Finally, Tozer (1990, p. 11; 1994b, p. 162) concluded that the classic Rhaetian represents only a provincial substage of the Norian, and thus has no place in the hierarchy of standard Triassic stages.

In the light of the actual stratigraphic rules, it is strange to see how at that time the dispute on the status of the Rhaetian was carried out in connection with the Kössen Beds, a purely lithostratigraphic unit, instead of recognizing the Rhaetian as a chronostratigraphic unit.

Ultimately, by adopting the Norian-Rhaetian boundary as defined by Krystyn $(1988,1990)$ on the basis of the ammonoid sequence in the Zlambach Marls, Golebiowski (1990, p. 30) definitely demonstrated that the Kössen Formation includes both Norian and Rhaetian beds, with Rhabdoceras suessi occurring in the lower Rhaetian. As the base of the Kössen Formation is situated somewhere within the Upper Norian without any time-significant fossils below, Golebiowski (1990) and Krystyn (1990) concluded that its base is not suitable as a chronostratigraphic boundary between the Norian and Rhaetian. Thus, for the first time a clear discrimination was made for the Kössen Formation as a lithostratigraphic unit and for the Rhaetian as a chronostratigraphic one; the latter, however, not yet having a proper definition.

The long controversy around the status of the Rhaetian as a stage, substage or unit with no significance in global chronostratigraphy as illustrated in the Figs 4 and 5, ended during the STS Meeting in Lausanne in 1991, when a significant majority of STS members decided to retain the concept of a separate Rhaetian Stage, a decision that was ratified at the STS Meeting in Kyoto on 31 August 1992 (Visscher 1992). Several operational definitions utilizing ammonoids have been used in Europe in the following years to define the base of the Rhaetian, i.e. the base of the Vandaites stuerzenbaumi Zone (Krystyn 1988), the base of the Sagenites quinquepunctatus Zone (Shevyrev 1991), the base of Sagenites reticulatus Zone (Dagys and Dagys 1994), or the base of the 'Cochloceras' suessi Zone (Kozur 
2003a-b), but again without a selected stratotype. The controversial placement of the base of the Rhaetian, and the different temporal extents given to this stage, led to serious complications in the chronostratigraphy of the uppermost Triassic, due to a conflicting overlap of the Lower Rhaetian (Sevatian 2) with the upper part of the Norian substage (Sevatian 1).

In North America, Carter (1993) revived the Rhaetian, with its base being marked by a strong change in radiolarians that occurred in close temporal proximity to the appearance of the ammonoid Paracochloceras. Afterwards, Orchard and Tozer (1997) selected the base of the Paracochloceras amoenum Zone to define the Norian/Rhaetian boundary, thus ultimately reinstalling the Rhaetian as the uppermost stage in the North American Triassic time scale. The stage status of the Rhaetian is now currently installed in the North American Triassic timescale (e.g. Orchard et al. 2007; Carter and Orchard 2007; Katvala and Stanley 2008; Caruthers and Stanley 2008; McRoberts 2010).

Following the STS 2003 Executive Notes (Albertiana 28), the lowest occurrence of the ammonite Cochloceras/Paracochloceras has officially been nominated as a proxy for an internationally agreed Norian/Rhaetian boundary, with possible GSSP candidates in key sections in Austria, British Columbia (Canada), and Turkey (Ogg 2004a-b).

Further studies in the Northern Calcareous Alps have been focused on the pelagic facies in the Hallstatt Basin with the aim to identify and define a Rhaetian stratotype reliable enough to fulfill the necessary requirements to define chronostratigraphic units achieving general consensus for a basal boundary supported by multiple proxies (Walsh et al. 2004). Results published by Krystyn and Kuerschner (2005), Krystyn et al. (2007a, b), Krystyn (2008a, b) have demonstrated the faunistic and biochronologic significance of the Steinbergkogel section near Hallstatt, in the Austrian Salzkammergut region, as a GSSP for the base of the Rhaetian Stage. In terms of the newly gained, detailed ammonoid biochronology, the Norian-Rhaetian boundary may be defined by the disappearance (LO) of the ammonoid genera Metasibirites and Sagenites s.l. (with lateral nodes) or by the appearance (FO) of Paracochloceras suessi and Sagenites s. str., while in terms of pelagic bivalve biochronology the same boundary is marked by the worldwide disappearance of Monotis salinaria/subcircularis in low and mid-paleolatitudes and M. ochotica group in the Boreal Zone.

However, by allocating the Paracochloceras suessi Zone to the Rhaetian Stage, it results that the Sevatian Substage of the classic Norian Stage in the Alpine Triassic time scale is now split in two distinct parts, whereby the Sevatian 2, with the ammonoid Paracochloceras as a biostratigraphic guide, becomes the equivalent of the Lower Rhaetian. As the chronostratigraphic nomenclature is essentially a matter of consensus, to avoid further conceptual and nomenclatural misunderstandings that can plague stratigraphers, it is necessary, as in many other cases in the Geologic Time Scale, when the GSSP levels defining stages have necessitated a revision of the historical usage (Ogg 2004a), that the STS 
should limit the Sevatian only to the Upper Norian in the sense of the actual Triassic time scale standard. This is already given, but not explicitly stated, by Krystyn et al. (2009), Lucas (2010) and Balini et al. (2010).

In summary, after more than 150 years of long-lasting controversy over the scope, content, acceptance or refusal of the Rhaetian, it is now unanimously accepted as a distinct stage for the uppermost Triassic having a GSSP candidate for its basal boundary in the Steinberkogel section that exposes a pelagic basin facies of the red and gray Middle Norian to Lower Rhaetian Hallstatt Limestone, and having a highly resolved ammonoid chronology.

\section{Paleobiogeography}

The geographical distribution of Rhabdoceras suessi has been formerly summarized and mapped by Wiedmann (1973), Tozer (1980b-c, 1982a) and Shevyrev (2005). We present here an up-to-date worldwide distribution map, on both present-day and Triassic geographic coordinates, including all occurrences recorded in the published papers (Fig. 6).

As shown by the distribution map, the heteromorphic ammonoid Rhabdoceras suessi occurs mainly along the Pacific margins of North and South America, in numerous locations along the Alpine-Himalayan orogenic belt, and also has isolated occurrences in Indonesia and Northeast Asia. The ammonoid Rhabdoceras had a pandemic distribution during Late Triassic (Late Norian and Rhaetian) time in low- and mid-paleolatitude faunal provinces along the eastern margin of the Panthalassa (paleo-Pacific Ocean) and also in the Tethys Seaway, this distribution being constrained by other groups of biogeographically significant macrofossils. This heteromorphic ammonoid did not inhabit the Boreal and Notal provinces.

The most spectacular, and also the most intriguing, occurrences of Rhabdoceras are those in the North American Cordillera, where they extend over a broad latitudinal range, which is not reflected in the original Triassic biogeography, and is the consequence of the complex accretionary and post-accretionary tectonics

Fig. $6 \rightarrow$

World distribution (Mercator projection) of Rhabdoceras suessi, as defined in the text. A similar base map to that of Silberling (1985) is used in order to compare with the world distribution of Monotis faunas. Alpine orogenic belts are highly generalized from Dickinson et al. (1986), and the Upper Triassic paleolatitudes, shown for the continental blocks, are from Irving (1979). North American craton-bound and craton-related occurrences: Locs 1-2 - northeastern British Columbia; Locs 3-7 western Nevada; Loc. 8 - northwestern Sonora, Mexico; Accreted terranes of North American Cordillera: Loc. 9 - Puale Bay, Alaska; Loc. 10 - southern Yukon; Loc. 11 - southern British Columbia; Locs 12-14 - Vancouver Island; Loc. 15 - Queen Charlotte Islands; Locs 16-17 - northern California; South American Cordillera: Loc. 18 - Ortes Payandé, Colombia; Loc. 19 - Levanto, Peru; Accreted terranes in Northeast Russia: Loc. 20 - Western Chukotka; Alpine-Himalayan-Indonesian orogenic belt: Locs 21-29 - Northern Calcareous Alps, Austria; Loc. 30 - Sicily; Loc. 31 -Transdanubian Range, Hungary; Loc. 32 - Slovakia; Loc. 33 - Eastern Carpathians, Romania; Loc. 34 - Balkans, Bulgaria; Loc. 35 - southern Pamirs; Loc. 36 - Misool Island; Loc. 37 - West Timor; Loc. 38 - Timor-Leste 


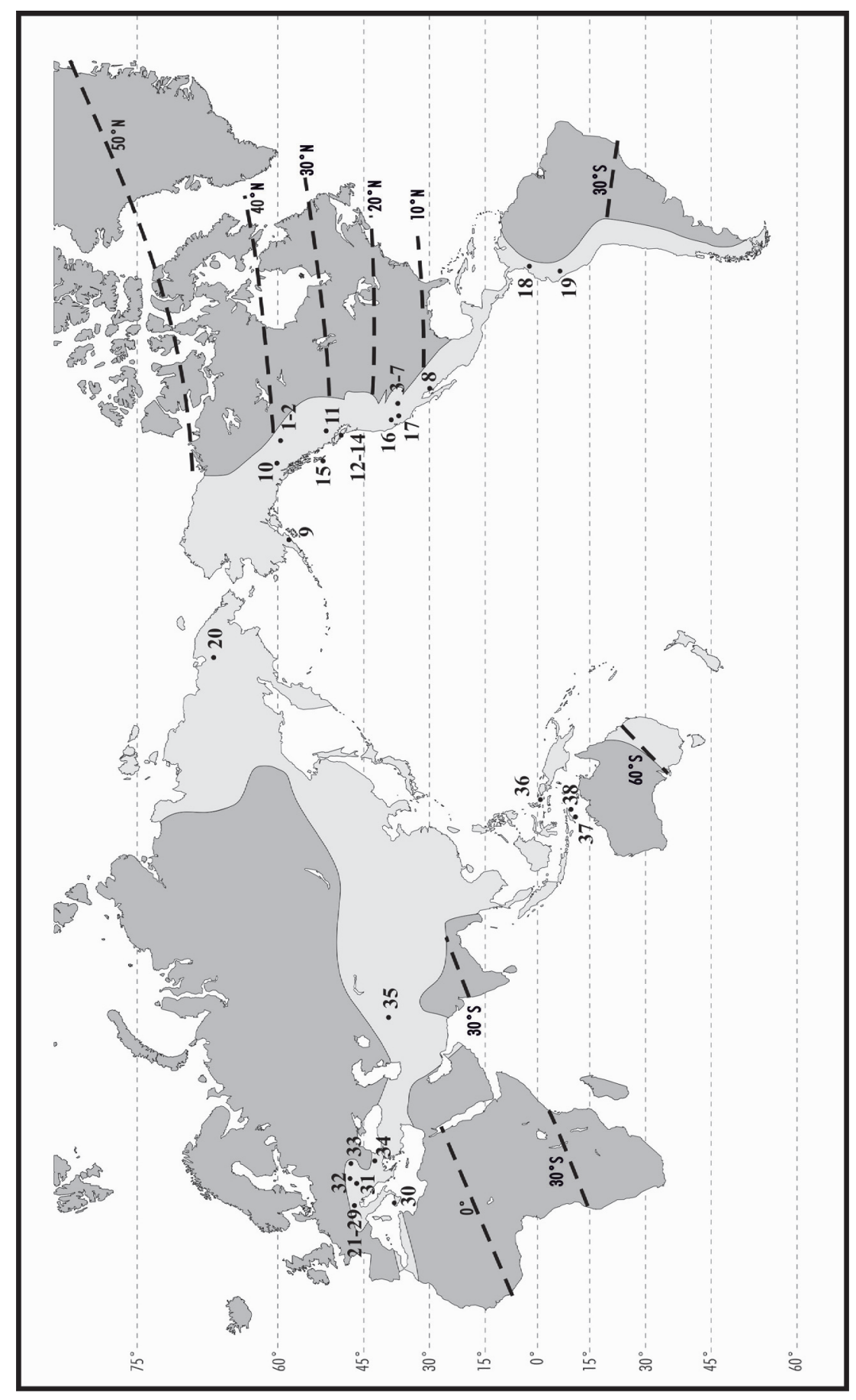

Central European Geology 53, 2010 
that affected the western North American margin. A large amount of varied data, paleontological, stratigraphic, paleogeographic, biogeographic, paleomagnetic and tectonic, have contributed to the deciphering of the terrane puzzle of the North American Cordillera (e.g. Howell et al. 1985; Haggart et al. 2006; Blodgett and Stanley 2008).

Pacific margins of North and South America

Along the Pacific margins of North and South America, from Alaska to Peru, the heteromorphic ammonoid Rhabdoceras suessi has known occurrences in both craton-bound Upper Triassic strata and in those of the American Cordillera terranes, many of them being reported from the accreted terranes.

Although the occurrences of Rhabdoceras do not provide positive evidence by itself for the paleolatitude assessment and displacement of the various American Cordilleran accreted terranes, the intrinsic character of the co-occurring Upper Triassic faunas, which include various groups of biogeographically significant biotas, ammonoids, monotids and reef biotas, is suggestive for its occurrence in low and middle paleolatitudes.

An obvious paleolatitudinal control existed on the distribution of different Upper Triassic ammonoid and monotid faunas from different segments of the North American cratonic margin and the Western Cordillera (Westermann 1973; Nichols and Silberling 1979; Tozer 1980c, 1982a, 1984; Silberling 1985; Silberling et al. 1997). Various fossil biotas give precious insight into the Upper Triassic marine biogeography of the continental shelf along the western margin of the North American craton, much of which was subsequently obscured by the complex accretionary tectonics of Triassic terranes (e.g. Tozer 1982a; Stanley 1982; Silberling 1985; Blodgett and Stanley 2008).

In the Western Cordillera and Arctic North America, Upper Triassic ammonoid and monotid faunas are apparently distributed according to original paleolatitude in rocks depositionally or sedimentologically related to the North American craton. The regional differences among North American Upper Triassic ammonoid and monotid faunas provide a good basis for paleobiogeographic and tectonostratigraphic terrane analysis. Distinct ammonoid and monotid faunas are recognized on the basis of their mutual occurrence or exclusion of certain of the taxonomic groups, and these have discrete geographic distribution. Paleomagnetic control on the paleolatitudes of the accreted terranes of the North Pacific margin generally corroborates the assumption that latitude was the primary biogeographic control. Tozer (1982a), Silberling (1985) and Silberling et al. (1997) segregated craton-bound ammonoid and monotid faunas of broadly different paleolatitudes in the Northern Hemisphere. Inboard of the Phanerozoic accreted terranes, exposures of craton-bound, or craton-related, fossiliferous marine Upper Triassic rocks from western Nevada, the Rocky Mountain Foothills of western Canada, Arctic Alaska and the Canadian Arctic Islands (Sverdrup 
Basin) allow comparisons between, respectively, low, low-middle, middle-high and high, northern paleolatitude faunas.

Comparison between the North American craton-bound Monotis faunas and those of the Western Cordilleran terranes indicates that all of the Monotis-bearing terranes were paleoequatorial in latitude during Late Triassic time. Paleolatitudinal distribution of the Upper Triassic ammonoids and of the different species of Monotis varied, and thus they provide important paleogeographic constraints for interpreting the displacement histories of the various Western Cordilleran accreted terranes. Large-scale displacement of the accreted terranes is evidently required to explain the present distribution of the Upper Triassic ammonoid and monotid faunas, and it represents a major constraint in assessing the paleobiogeographic distribution of the heteromorphic ammonoid Rhabdoceras in the eastern part of the Panthalassa.

North American craton. The western margin of the North American craton preserves autochthonous and para-autochthonous marine Triassic, where three faunal provinces have been distinguished by Tozer (1982a) on the basis of their diagnostic fossils, and designated by their present-day latitude as the low, middle and high paleolatitude provinces. From south to north, these paleolatitudinal provinces are in their approximate hemispheric position along the North American Pacific craton margin. Low-paleolatitude faunas occur in the Triassic strata of the para-autochthonous terranes in the western Great Basin of western Nevada, while mid- to high-paleolatitude faunas are found in the Upper Triassic craton-bound strata of northeastern British Columbia and Arctic Canada, respectively.

The province now at low latitude has intrinsic Upper Triassic characteristics, such as reefs and reef-like buildups, suggestive of deposits in warm water. These are absent in the province now at higher latitudes, suggesting that their faunas inhabited cooler waters, so these provinces more or less match the primary Triassic paleolatitudes (Tozer 1982a). In cratonic North America the occurrence of Rhabdoceras suessi is recorded only in the middle and low paleolatitude provinces, in the craton-bound Upper Triassic strata in northeastern British Columbia in Canada, and in the para-autochthonous strata of western Nevada in the United States, and in northwestern Sonora in Mexico, respectively (Fig. 7).

In northeastern British Columbia, the occurrence of Rhabdoceras suessi is mentioned from the Cordilleranus and Amoenum Zones (Figs 6 and 7, Locs 1-2).

Loc. 1 - Peace River, Ne-parle-pas Rapids, Rhacophyllites beds, Pardonet Formation (Tozer 1965, p. 222; 1967, pp. 54-55; 1979, p. 128; 1982b, p.387; 1994a, pp. 46, 265, pl. 144, figs 1-2, pp. 322, 346; Wignall et al. 2007, p. 392); Amoenum Zone.

Loc. 2 - Mount Ludington, Monotis beds, Pardonet Formation (Tozer 1967, pp. 54-55; 1979, p. 127, pl. 16.1, figs 8a-c; 1982b, p. 387; 1994a, pp. 45, 265, pl. 144, figs 5-8, pp. 331-332, 345); Cordilleranus Zone.

Both localities are in the Eastern Belt of the Canadian Cordillera, which adjoins and is essentially autochthonous with respect to the North American craton (Tozer 1982a, 1994a). This region is the only one in western North America where 


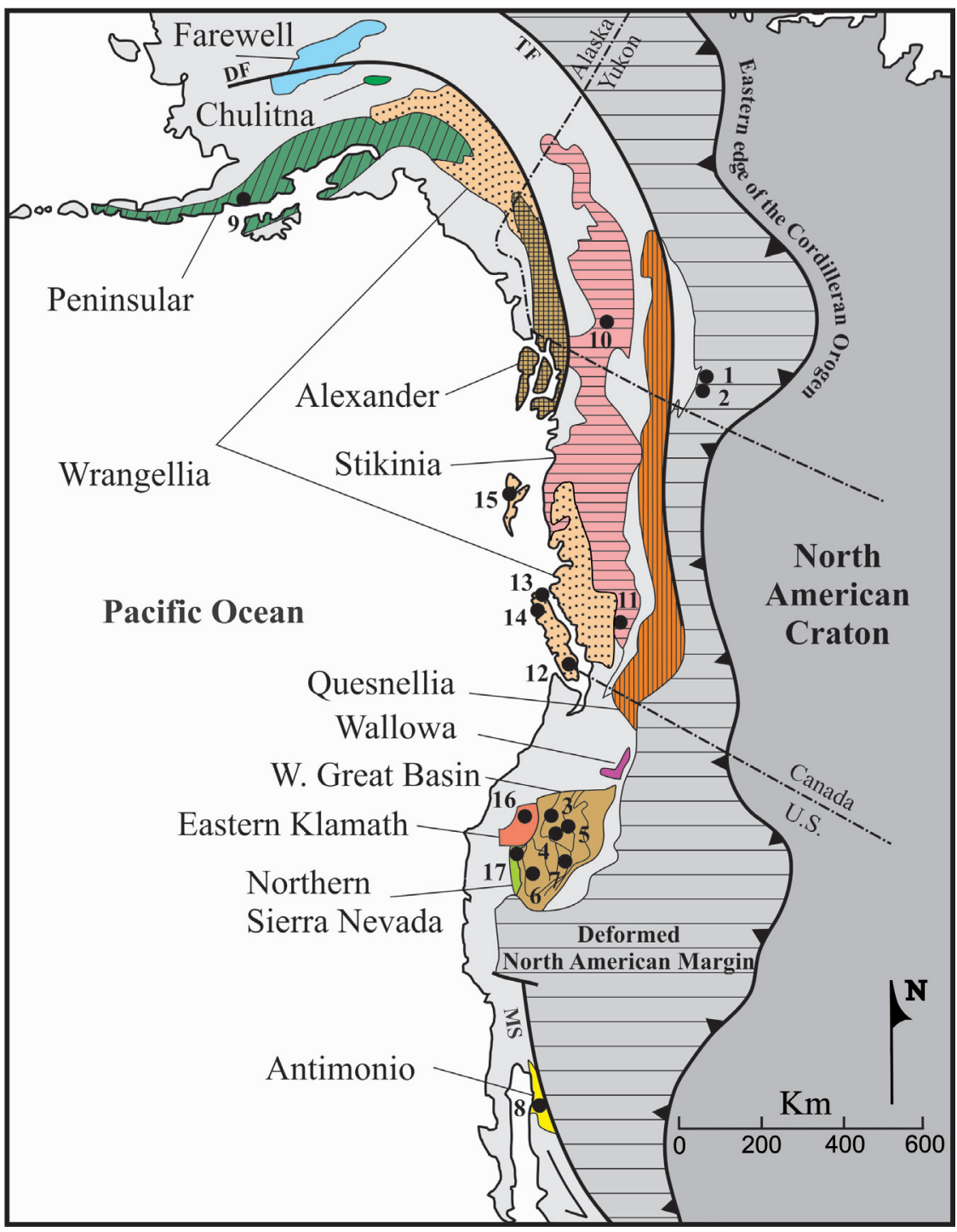

Fig. 7

Sketch map of Western North America showing the distribution of Rhabdoceras suessi as discussed in text. Craton-bound occurrences of middle paleolatitude: Locs 1-2 - northeastern British Columbia; Craton-related occurrences of low paleolatitude: Locs 3-7 - western Nevada; Loc. 8 - northwestern Sonora, Mexico; Occurrences in accreted terranes of North American Cordillera: Peninsular, Loc. 9 Puale Bay, Alaska; Stikinia, Loc. 10 - southern Yukon, Loc. 11 - southern British Columbia; Southern Wrangellia, Locs 12-14 - Vancouver Island, Loc. 15 - Queen Charlotte Islands; Eastern Klamath, Loc. 16 - Brock Mt; Northern Sierra Nevada, Loc. 17 - Sierra Nevada. DF - Denali Fault, TF - Tintina Fault, MS - Mojave-Sonora megashear. Terrane map compiled from Silberling (1990), Senowbari-Daryan and Stanley (2009), and Blodgett and Frýda (2001b) 
Rhabdoceras suessi occurs in sequence within the Cordilleranus and Amoenum Zones, and this served for Tozer $(1967$, pp. 39, 55) to divide the former Upper Norian Suessi Zone into two parts, i.e. the Lower Suessi Zone, and the Upper Suessi Zone that overlie Monotis (P.) subcircularis-bearing strata. The Monotis fauna which is well documented in the Upper Triassic cratonic shelf of northeast British Columbia (Westermann and Verma 1967; Tozer 1967, 1979, 1982a-b, 1994a), indicates northern, mid- to high-paleolatitudes (Silberling 1985; Silberling et al. 1997). In the Peace River area, beds with Monotis (P.) subcircularis and M. (Entomonotis) ochotica, which are correlatives of the Upper Norian Cordilleranus Zone, overlie M. (Eomonotis)-bearing strata of the late Middle Norian Columbianus Zone. The Peace River Foothills represent the southernmost occurrence of $M$. (Eomonotis) pinensis on the craton. The presence of $M$. (Entomonotis) ochotica and the absence of corals and megalodonts are characteristic features for the mid-paleolatitude province. The scleratinian coral and spongiomorph-bearing patch reefs in the Upper Carnian Baldonnel Formation at Pardonet Hill in northeastern British Columbia document the occurrence of Triassic corals on the North American craton margin at $\sim 30^{\circ} \mathrm{N}$ paleolatitude, the extreme latitudinal edge of the subtropical zone (Zonneveld et al. 2007). Their absence in younger Triassic strata of the Rocky Mountain Foothills could be explained by the northward displacement of the North American plate to higher, mid-latitudes in the Northern Hemisphere during Late Triassic time, which is demonstrated by the paleobiogeographic signature of the monotid fauna.

In western Nevada, Rhabdoceras suessi is mentioned in several localities (Figs 6 and 7, Locs 3-7), most of the occurrences being in the Cordilleranus Zone, and a single occurrence being recorded in the Amoenum Zone.

Loc. 3 - Northern Clan Alpine Range, Hoyt Canyon Formation (Silberling, in Silberling and Tozer 1968, p. 31); Cordilleranus Zone.

Loc. 4 - West Humboldt Range, Muttleberry Canyon, Monotis beds (Hyatt and Smith 1905, pp. 17, 26, 33, 203, pl. 56, fig. 26; Smith 1927, pp. 2, 9, 20, 99, pl. 56, fig. 26); Cordilleranus Zone.

Loc. 5 - Humboldt Range, Buffalo Mountain; Monotis beds, Upper unit of post-Dun Glen strata (Silberling and Wallace 1969, p. 47); Cordilleranus Zone.

Loc. 6 - Pine Nut Mountains, Oreana Peak Formation (Silberling, in Stewart 1997, p. 32); Cordilleranus Zone.

Loc. 7 - Gabbs Valley Range, Gabbs Formation, Nun Mine Member (Muller and Ferguson 1939, p. 1605; Silberling and Tozer 1968, p. 31; Laws 1982; Taylor et al. 1983); Amoenum Zone.

The Triassic in the first two localities are in the Jungo terrane, while those in the third locality belong either to the Jungo or the Golconda terrane. The Triassic of the last two localities are in the Pine Nut and Paradise subterranes, respectively, both being included in the Walker Lake terrane (Silberling 1990). All these terranes and subterranes are regarded as belonging to a tectonically disrupted continuation of the Mesozoic continental margin and unlike truly allochthonous terranes they are para-autochthonous, and thus are not exotic with respect to the North American craton at about their present latitude (Silberling 1985; Lupe and Silberling 1985). 
In the Cordilleranus Zone of these localities, Rhabdoceras suessi occurs together with Monotis (Monotis) alaskana Smith, M. (M.) haueri Kittl, M. (Pacimonotis) subcircularis Gabb and the hydrozoan Heterastridium. In terms of the monotid biogeography, M. (M.) alaskana is considered a biogeographic hallmark of low paleolatitudes. Other significant biogeographic evidence for an originally lowpaleolatitude deposition of the Upper Triassic strata in the Nevadan cratonbound terranes is provided by the Middle Triassic pteriomorphian bivalves and scleractinian corals from the Augusta Mountain Formation, and also the Late Triassic brachiopods, spongiomorphs and wallowaconchid bivalves (Sandy and Stanley 1993; Roniewicz and Stanley 1998; Yancey et al. 2005; Senowbari-Daryan and Stanley 2009).

In Mexico, Rhabdoceras suessi has its southernmost known occurrence in the Western Cordillera (Figs 6 and 7, Loc. 8).

Loc. 8 - Sierra del Álamo, northwestern Sonora, Antimonio Formation (González-León et al. 2000, pp. 492-494, text-fig. 5.8-10); Crickmayi Zone.

An Upper Triassic shallow-water, reef-like invertebrate fauna, including calcified sponges, spongiomorphs, corals, along with the hydrozoan Heterastridium, ammonoids, wallowaconchid bivalves, suggestive of a tropicalparatropical climatic zone, occur within a biostromal limestone in the lower member of the Antimonio Formation (Stanley et al. 1994; Stanley and GonzálezLeón 1995; Goodwin and Stanley 1997). For the Cordilleran region the Antimonio fauna shows its closest biogeographic ties with those of craton-bound Norian strata of para-autochthonous North American terranes in the Great Basin of west-central Nevada (Luning Allochthon). Middle Norian gastropod faunas of the Antimonio Formation were noted by Blodgett and Frýda (2001a) and Frýda and Blodgett (2003) to be nearly identical to those of western Nevada, and they suggested a single province, the "Nevada-Sonora", to encompass them. Paleobiogeographic links with Nevada appear stronger than with Cordilleran terranes of the United States or Canada. To explain stratigraphic and paleontological similarities between west-central Nevada and northwestern Sonora, Stanley and González-León (1995) postulated that the Antimonio terrane could have been tectonically displaced southward along the Mojave-Sonora megashear, by as much as $1000 \mathrm{~km}$, into its present-day position in northwestern Sonora, by left-lateral transcurrent faulting along the truncated Mesozoic edge of the North American craton, from original depositional settings in the southwestern United States. The Antimonio para-autochthonous terrane appears to be a detached portion of the Cordilleran miogeocline that remained physically in contact with the North American craton (Yancey et al. 2005).

North American Cordillera. Most of the known occurrences of Rhabdoceras suessi in North America, as plotted in Figs 6 and 7, are reported from the Western Cordillera of North America, which represents a belt of fault-bounded, accreted or displaced (also referred to as allochthonous, suspect or exotic) tectonostratigraphic (also referred to as lithotectonic) terranes and subterranes (e.g. 
Coney et al. 1980; Jones et al. 1983, 1986, 1987; Saleeby 1983; Howell et al. 1985; Monger and Berg 1987; Silberling et al. 1984, 1992; Gabrielse et al. 1991; Nokleberg et al. 1994; Dickinson 2004) that extends from Alaska to Mexico. More than 20 accreted terranes with marine Triassic rocks became amalgamated during the Jurassic, prior to Cretaceous accretion to the North American continental margin (Tozer 1982a), in a tectonic collage of a great structural complexity, most of them with geologic histories independent of the craton and also of each other. Since their accretion to North America, extensive right-lateral transcurrent faulting further modified the primary configuration and relationships of these terranes and dispersed them from their original latitudes to higher northern latitudes along the western edge of the North American craton. These tectonic complexities complicate correlation and matching of the terranes, as well as the reconstruction of their pre-accretionary paleogeography.

Biogeography is a powerful tool for interpreting the paleogeographic position of the accreted terranes and for assessing their large-scale displacements within the North American Cordillera. Taxonomic studies and biogeographic interpretation of different fossil biotas help to elucidate relations among accreted terranes and to constrain their past geographic positions over time with respect to the craton, thus being of utmost utility in unraveling the tectonic history of the North American Cordillera (e.g. Silberling and Jones 1983; Carter et al. 1991; Haggart et al. 2006; Blodgett and Stanley 2008). To test paleogeographic and tectonic hypotheses, fossil evidence in conjunction with paleomagnetic data must be considered to result in a more precise estimate of the origin of the allochthonous terranes, as well as the timing of their accretion to North American craton.

Most of the Triassic faunas throughout the North American Cordilleran accreted terranes include fossils diagnostic for the low-paleolatitude province defined on the North American craton. All are now north of the craton-bound occurrences in the Clan Alpine and Gabbs Valley ranges, in western Nevada. Some are now aligned latitudinally with the mid-paleolatitude province on the craton in western Canada. In Alaska and Yukon they are about $3000 \mathrm{~km}$ north of their counterparts on the North American craton and about $1500 \mathrm{~km}$ north of the mid-paleolatitude province in British Columbia (Tozer 1982a).

The significance of various Upper Triassic faunas in assessing the former paleogeographic position of displaced terranes has been highlighted by numerous authors (e.g. Westermann 1973; Tozer 1970, 1971, 1982a, 1984, 1994a; Stanley 1982; Newton 1988; Silberling 1985). The ammonoids and monotid bivalves are the most investigated among the biogeographically significant biotas for the Late Triassic paleogeography of the Cordilleran accreted terranes (Tozer 1982a, 1994a; Silberling 1985; Silberling et al. 1997). Scleractinian coral, spongiomorph and sponge-dominated reef biota represent the most significant fossil group for assessing the paleogeographic signature of the accreted terranes. Upper Triassic Dachstein-type, massive tropical reefs, and coral-rich biostromal 
and patch-reef buildups occur within island-arc settings of many of inboard displaced terranes of the North American Cordillera, such as in the Chulitna terrane in Alaska, the Alexander, Wrangellia, Stikinia and Quesnellia terranes in Canada, the Wallowa and Eastern Klamath terranes in the western United States, and the Antimonio terrane in Mexico (Stanley and Senowbari-Daryan 1986; Reid and Tempelman-Kluit 1987; Goodwin and Stanley 1997; Yarnell et al. 1999; Stanley and Senowbari-Daryan 1999; Stanley and Yarnell 2003; Caruthers and Stanley 2008; Senowbari-Daryan and Stanley 2009). The reef biota, together with wallowaconchid bivalves (Yancey et al. 2005), and gastropods (e.g. Blodgett et al. 2001; Blodgett and Frýda 2001b; Nuetzel et al. 2003), provide compelling biogeographic evidence for a low-paleolatitude origin of these terranes and indicate tropical-subtropical climate regimes in the eastern region of the Panthalassa Ocean. The spherical, planktonic hydrozoan Heterastridium conglobatum Reuss, 1865, a common associate of Monotis faunas in the Upper Norian Cordilleranus Zone, is also noteworthy because of its biogeographic significance. It is abundant in a large number of accreted terranes and subterranes, i.e. Chulitna, Peninsular, Alexander, Wrangellia, Susitna, Farewell (Nixon Fork subterrane), Quesnellia, and Antimonio, where it is often closely associated with strata bearing other warm-water elements such as scleractinian corals, spongiomorphs, etc. (Silberling and Tozer 1968; Tozer 1982a, 1994a; Silberling et al. 1997; Stanley and González-León 1995; González-León et al. 1995; Blodgett and Clautice 2000; Katvala and Stanley 2008). All these fossil biotas, occurring in Upper Triassic strata of the tectonostratigraphic terranes accreted along the North American continental margin, show that the Western Cordillera contains shallow-water carbonate buildups, many of which once rimmed volcanic oceanic islands situated in the equatorial region of eastern Panthalassa (paleo-Pacific Ocean) during Late Triassic time.

The wide latitudinal range in terms of present-day geographic distribution (not reflective of their original tropical origin) of all these Upper Triassic biotas in the accreted terranes of the Western Cordillera, express the post-Triassic, northward, large-scale tectonic displacements of these terranes with respect to the contemporary non-accretionary occurrences on the North American craton, as earlier pointed out by Tozer (1982a), Stanley (1982) and Silberling (1985).

In regards to the broad latitudinal occurrences of Rhabdoceras suessi in the accreted terranes of the Western Cordillera and their paleobiogeographic signature, this heteromorphic ammonoid shares a low-paleolatitude origin in common with the coevally-occurring biotas.

In the Western Cordillera of Alaska, the only known occurrence of the heteromorphic ammonoid Rhabdoceras is reported from southwestern Alaska (Figs 6 and 7, Loc. 9).

Loc. 9 - Alaska Peninsula, Puale Bay, Kamishak Formation (Pálfy et al. 1999, p. 1538), Peninsular terrane, Chignik subterrane; Cordilleranus Zone. 
This is the northernmost occurrence of Rhabdoceras suessi in the accreted terranes of the North American Cordillera. It co-occurs in the Kamishak Formation with Monotis (Pacimonotis) subcircularis Gabb, Monotis (Monotis) alaskana Smith, M. (Entomonotis) sp. cf. M. (En.) ochotica densistriata (Teller) and the hydrozoan Heterastridium (Grant-Mackie and Silberling 1990; Silberling et al. 1997; Blodgett 2008). Paleomagnetic data, the lithology and the paleobiogeographic affinities of the various Late Triassic faunas found in the Kamishak corroborate its low paleolatitude in a definite northern hemisphere location, indicating that the Peninsular terrane was situated in a tropical to subtropical setting during the Late Triassic (Wilson et al. 1985; Detterman 1988, 1996; Blodgett 2008).

In the Western Cordillera of Canada, the accreted terranes are found in both the Intermontane and Insular belts, and all are interpreted as indicating that the Triassic rocks are allochthonous with respect to the North American craton. They show signs of having been deposited in relatively warm water at a lower paleolatitude than contemporary rocks now at the same present-day latitude in the cratonic Eastern Cordillera (Tozer 1970, p. 635; 1982a; 1994a, p. 20).

In the Intermontane Belt of the Cordillera, the occurrence of Rhabdoceras suessi is reported from both the Cordilleranus and Amoenum Zones (Figs 6 and 7, Locs $10-11)$.

Loc. 10 - Southern Yukon, Lewes River, Laberge area, Formation D, Lewes River Group (Tozer 1958, p. 15; 1963, pl. 12, figs 18-19; 1967, pp. 79-80, pl. 10, figs 6-7; 1970, p. 634, pl. 18, fig. 18a-b; 1994a, p. 265, pl. 144, figs 3-4, p. 303); Cordilleranus Zone.

Loc. 11 - Southern British Columbia, Castle Peak-Tyaughton Creek area and southern Coast Mountains, Cassianella Beds, Tyaughton Group (Tozer 1967, pp. 75-80; 1979, p. 127, pl. 16.1, fig. 10; 1994a, p. 265, pl. 147, figs 1-2, p. 322; Umhoefer and Tipper 1998, p. 21); Amoenum Zone.

Structurally the Triassic rocks of the Lewes River are included in the Stikine terrane while the Triassic rocks from Tyaughton Creek are uncertainly assigned either to the Stikine terrane by Tozer (1982a, p. 1082), to the Methow-Tyaughton terrane by Monger and Berg (1987) and Silberling et al. (1997, p.12), or to the Cadwallader terrane by Umhoefer and Tipper (1998) and McRoberts and Blodgett (2000, p. 58). The last two of these terranes could be fragments of the larger Stikine terrane. In the northern part of Stikinia, which relative to the North American craton lies in an inboard setting, only M. (P.) subcircularis and M. (M.) haueri are known to occur, while species of $M$. (Entomonotis), such as those that characterize craton-bound Late Norian Monotis faunas farther inland at about the same present-day latitude in north-eastern British Columbia, are unknown (Silberling et al. 1997). In the same stratigraphic succession as that containing the Monotis faunas, one of the few developments of paleoequatorial Dachstein-type Upper Triassic coral reefs in North America (Stanley and Senowbari-Daryan 1986; Reid and Tempelman-Kluit 1987; Yarnell et al. 1999) is displayed at Lime Peak in southern Yukon, the other being in the Wallowa terrane of eastern Oregon. Wallowaconchid megalodontoid bivalves are associated with coral-rich biotas in both terranes, indicating tropical-subtropical climate regimes in the eastern region of the Panthalassa Ocean from where these terranes originated (Yancey et 
al. 2005). The implications of the coral reefs for appreciable northward displacement of the Stikinia terrane relative to the craton was first recognized by Tozer (1970, 1982a).

In the Insular Belt of the Cordillera, Rhabdoceras suessi occurs in the Vancouver and Queen Charlotte Islands, in Cordilleranus, Amoenum and Crickmayi Zones (Figs 6 and 7, Locs 12-15).

Loc. 12 - Southern Vancouver Island, Cowichan Lake, Cape Flattery area, Sutton Formation (Tozer 1967, pp. 78-79; 1979, p. 128, pl. 16.1, fig. 9a-b; 1980c, pp. 854-855; 1994a, p. 265, pl. 147, fig. 3; p. 302); Crickmayi Zone.

Loc. 13 - Northeastern Vancouver Island, Walters Cove, Kyuquot, Supramonotis Beds (Arenaceous Member), Parson Bay Formation, (Tozer 1967, p. 80; 1980c, pp. 854-855; 1994a, p. 302; Muller et al. 1981, pp. 13-14; Carter and Orchard 2007, p. 151); Amoenum Zone.

Loc. 14 - Northwestern Vancouver Island, Clark Island, Nootka Sound area, Monotis beds (Thinly Bedded Member), Parson Bay Formation, (Tozer 1967, p. 80; 1980c, pp. 854-855; 1994a, pp. 290, 301-302; Muller et al. 1981, pp. 13-14; Carter and Orchard 2007, p. 151); Cordilleranus Zone.

Loc. 15 - Queen Charlotte Islands; Monotis beds, Peril Formation (Tozer 1980c, pp. 854-855); Cordilleranus Zone.

On Vancouver Island, Rhabdoceras suessi occurs in sequence within the Cordilleranus, Amoenum and Crickmayi Zones. This is the first North American locality where it was proved that Rhabdoceras ranges up into the latest Triassic Crickmayi Zone (Tozer 1979, p. 128), although its co-occurrence here with Choristoceras had been earlier noticed and considered unusual (Tozer 1967, p. 78). The Triassic rocks on Vancouver and Queen Charlotte islands are located in the southern Wrangellia terrane (e.g. Tozer 1982a, p. 1082). Monotis fauna, with M. (Pacimonotis) subcircularis and M. (M.) alaskana, is indicative of low paleolatitudes (Tozer 1982a; Silberling 1985; Silberling et al. 1887). This is also corroborated by the paleobiogeographic signature of the Rhaetian scleractinian coral fauna described by Caruthers and Stanley (2008) from the Cowichan Lake region.

In the Western Cordillera of the United States, Rhabdoceras-bearing allochthonous terranes are present in northern California, with known occurrences in the Cordilleranus Zone (Figs 6 and 7, Locs 16-17).

Loc. 16 - Brock Mountain, Shasta County, Brock Shale (Hyatt and Smith 1905, pp. 16, 33, 203, Smith 1927, pp. 2, 4, 20, 99); Cordilleranus Zone.

Loc. 17 - Sierra Nevada, Genesee Valley, Plumas County, Monotis beds (Hyatt and Smith 1905, pp. 26, 33, 203; pl. 47, figs 13-15; Smith 1927, pp. 2, 8, 20, 99; pl. 47, figs 13-15); Cordilleranus Zone.

The first occurrence is located in the Eastern Klamath terrane, akin to the inboard Quesnel superterrane (Wyld et al. 2006), while the second is located in the Northern Sierra Nevada terrane, or possibly in the part of the Eastern Klamath terrane structurally juxtaposed with the Northern Sierra terrane at its northern end (Silberling, pers. commun.). The Monotis fauna and reef biota of the Quesnellia, which like the Stikinia lies in an inboard setting relative to the North American craton, show that these accreted island arc terranes were situated within tropical-subtropical paleolatitudes of the Panthalassa Ocean (GrantMackie and Silberling 1990; Stanley and Senowbari-Daryan 1999; SenowbariDaryan and Stanley 2009). 
South American Cordillera. The heteromorphic ammonoid Rhabdoceras suessi has known occurrences in the Andes Mountains of Colombia and Peru (Fig. 6, Locs 18-19).

Loc. 18 - Payandé Formation, Ortes Payandé, Central Cordillera, Colombia (Geyer 1973, p. 24; Geyer 1979, p. 352); Cordilleranus and/or Amoenum Zones.

Loc. 19 - Aramachay Formation, Pucará Group, Utcubamba Valley, Levanto, northern Oriental Cordillera, Peru (Steinmann 1909, p. 617; Prinz and Hillebrandt 1994, pp. 35, 38; Hillebrandt 1994, p. 299, pl. 1, fig. 17); Amoenum Zone.

Specimens of Rhabdoceras sp. ex gr. suessi Hauer have been recorded along with Metasibirites annulosus Mojsisovics, M. tolymensis Geyer and Monotis (Pacimonotis) subcircularis Gabb from Colombia, while in Peru Rhabdoceras sp. and Metasibirites annulosus were found above Monotis (Pacimonotis) subcircularis Gabb. This is the only known Monotis species of the South American Cordillera (Westermann 1973; Tozer 1980c), and Silberling (1985) questioned whether its occurrences here are within accreted terranes. Both Mesozoic epicontinental series, the "Oriente Andino" of Colombia and the Mesozoic Pucará Basin in Peru define a pre-Andean paleogeography (Geyer 1979; Rosas et al. 2007). Although collisional docking of allochthonous terranes could have triggered local tectonism, it is believed that terrane accretion has not played a critical role in the Andean orogenesis (Dalziel and Forsythe 1985). The paleobiogeographic signature of the Upper Triassic sponges, corals, spongiomorphs and other associated shallow-water biotas from the Pucará Group is typical for low, southern paleolatitudes in the eastern Panthalassa Ocean (Stanley 1994).

\section{Pacific margins of Northeast Asia}

A remote occurrence of the heteromorphic ammonoid Rhabdoceras in Arctic Siberia is known from Western Chukotka (Fig. 6, Loc. 20).

Loc. 20 - Monotis ochotica beds, Privalninsky Formation, Bol'shoy Anyuy River Basin, Western Chukotka, Northeast Russia (Afitsky 1965, p. 137; 1966, p. 842; Afitsky 1970, pp. 20, 26, 30, 40, 106-108; Bychkov and Solov'ev 1992, pp. 12-13; Bychkov 2000, p. 105); Cordilleranus Zone.

Representatives of Rhabdoceras, with Rhabdoceras sp. and Rhabdoceras boreale, have been reported in the northeastern part of Northeast Russia by Afitsky (1965/1966, 1970). The Late Norian Monotis fauna shows a mixed character, with the Monotis (Entomonotis) ochotica group, M. (En.) pachypleura, and M. (En.) jakutica commonly typifying high and mid-paleolatitudes, along with low-paleolatitude monotids such as M. (M.) alaskana and M. (Pacimonotis) subcircularis (Bychkov 2000). The ammonoid assemblage includes Tethyan-type haloritids and longranging, cosmopolitan leiostracan genera. Hence, the species etymology for Rhabdoceras boreale Afitsky, 1965, does not properly reflect its occurrence at a high, northern paleolatitude during the Late Triassic, but its present-day occurrence at a high, northern latitude. On the Circum-North Pacific tectonostratigraphic terrane map of Nokleberg et al. (1994, p. 56) and Parfenov et al. (2009, p. 23) the Triassic volcano-sedimentary sequence from the upper reaches of the Bol'shoy 
Anyuy River is allocated to the Yarakvaam island arc terrane of the KolymaOmolon Superterrane. This superterrane consists of a tectonic collage of cratonic, passive continental margin, island arc and ophiolite terranes accreted to the northeast Verkhoyansk (North Asian) craton margin in Late Jurassic to Early Cretaceous time. The Monotis fauna of the Yarakvaam terrane, where the Middle Norian Monotis (Eomonotis) scutiformis Zone is followed by Late Norian monotids of the Monotis ochotica group (Bychkov and Solov'ev 1992), is comparable in its taxonomic composition with the mid-paleolatitude Monotis fauna from the Nixon Fork subterrane of the Farewell terrane in west-central Alaska, as described by Silberling (1985), Grant-Mackie and Silberling (1990) and Silberling et al. (1997). Both terranes also have in common the northernmost occurrence of the hydrozoan Heterastridium in the accreted terranes of the North American Cordillera and Northeast Asia, respectively.

\section{Alpine-Himalayan-Indonesian orogenic belt}

In the Neotethyan Alpine-Himalayan-Indonesian orogenic belt, the heteromorphic ammonoid Rhabdoceras suessi is discontinuously recorded from Alpine Europe and Central Asia, from Sicily, the Alps, the Carpathians, the Hungarian Transdanubian Range and the Balkans, and farther east the Pamirs and, after a large geographic gap, from the Moluccan Archipelago and Timor Island in Southeast Asia, along more than 20,000 km of Tethyan margin. Most of the occurrences are from Hallstatt limestone, which for the most part is allochthonous. An original distribution within $30^{\circ}$ of the Triassic equator for the Tethyan ammonoid and monotid bivalve faunas is generally accepted and is corroborated by the reef biotas, some internal paleomagnetic control and by the paleolatitudinal constraints provided by the continental blocks to the north (Eurasia) and south (Gondwana) of the Alpine-Himalayan orogenic belt (e.g. Tozer 1980b, 1982a; Silberling 1985; Krystyn and Piller 2000). In comparison with the broad latitudinal range of occurrences of Rhabdoceras suessi along the western North American margin, resulting from complex post-Triassic northward tectonic displacements, the geographic distribution of this ammonoid in the different regions of the Alpine-Himalayan-Indonesian orogenic belt remained closely confined within the belt, although the tectonostratigraphic units hosting it were also involved in large-scale post-Triassic movements.

Alpine Europe. The most numerous occurrences of Rhabdoceras suessi in Alpine Europe are known from the Northern Calcareous Alps in Austria (Fig. 6, Locs 21-29). This heteromorphic ammonoid is known from varied facies: pelagic facies of Hallstatt Limestone, basinal marly facies of Zlambach Beds, shallow-water facies of Dachstein carbonate platform, and mixed intraplatform facies of the Kössen Beds. Following the ammonoid biozonation for the uppermost Triassic of Alpine Europe, the biostratigraphic range of Rhabdoceras suessi extends from the Upper Norian (=Sevatian 1) into the Rhaetian.

Loc. 21 - Zlambach Beds, Mühlgraben, Grünbachgraben, Bad Goisern (Kittl 1903, p. 16; Wiedmann 
1972; Bolz 1974; Krystyn 1988); Stuerzenbaumi and Marshi Zones (= Crickmayi Zone).

Loc. 22 - Kössen Beds, Weißloferbach near Kössen, Achensee, Lahnwiesgraben near Garmish (Urlichs 1972; Wiedmann 1972; Möstler et al. 1978; Golebiowski 1986, 1990); Stuerzenbaumi and Marshi Zones (=Crickmayi Zone).

Loc. 23 - Dachstein-Riffkalk, Gosaukamm, and "erratische Blöcke", Falmbergalm near Gosau (Zapfe 1962, p. 348; Zapfe 1965, p. 300, pl. 1, fig. 8; Zapfe 1967, p. 20; Krystyn et al. 2009); Reticulatus Zone (= Amoenum Zone).

Loc. 24 - Gray Hallstatt Limestone, Steinbergkogel, Hallstatt (Mojsisovics 1893, p. 808; 1902, p. 343; Krystyn et al. 2007a-b; Krystyn 1991, 2008); Quinquepunctatus, Reticulatus and Stuerzenbaumi Zones ( $=$ Cordilleranus - lower Crickmayi Zones).

Loc. 25 - Red Hallstatt Limestone, Scheiblkogel, Bad Aussee, Austria (Gallet et al. 1996, p. 116); Quinquepunctatus Zone (= Cordilleranus Zone).

Beside the above-listed occurrences, which were found in sections of normal stratigraphic succession, Rhabdoceras suessi is known from several ammonoid assemblages, described in classical monographs, which came from fissure fillings, some of them with polyzonal ammonoid faunas (Krystyn et al. 1971; Tozer 1967, 1980c).

Loc. 26 - Fissure with "Weisser Crinoidenkalk", Steinbergkogel (Mojsisovics 1893, p. 808; 1902, p. 343; Krystyn 2008, p. 95); Middle Rhaetian.

Loc. 27 - Fissure with Cladiscites ruber, Millibrunnkogel (Hauer 1860, p. 125, pl. 2, figs 9-16; Mojsisovics 1893, p. 804; 1902, p. 341); Mixed faunas: Middle Norian to Lower Rhaetian.

Loc. 28 - Fissure with Sagenites giebeli, Lieslingwand (Mojsisovics 1893, p. 803; 1902, p. 804; 1902, p. 341); Mixed faunas: Middle and Upper Norian (= Sevatian 1).

Loc. 29 - Lens with Glyphidites docens, Röthelstein near Aussee (Mojsisovics, 1893, p. 804; 1902, p. 341); Mixed faunas: Middle and Upper Norian (= Sevatian 1).

Several isolated occurrences of Rhabdoceras suessi in Alpine Europe are known from Sicily in the southern Apennines, from Hungary in the NE Transdanubian Range, from Slovakia and Romania in the Carpathians, and from Bulgaria in the Balkans (Fig. 6, Locs 30-34).

Loc. 30 - Formazione Sciacca, Panormide Carbonate Platform, Monti di Palermo, Sicily, Italy (Gemmellaro 1904, p. 76, pl. 18, figs 45-46; Gemmellaro 1923, p. 138; Catalano et al. 1974, p. 1034; Antonelli et al. 1992, p. 163); Cordilleranus Zone.

Loc. 31 - Dachstein Limestone in Buda Mts, and Feketehegy Formation in Pilis Mts, NE Transdanubian Range, Hungary (Kutassy 1927, p. 165, pl. 6, fig. 8a-c; Kutassy 1932, 1936, p. 1041, pl. 13, fig. 36; Oravecz 1961, p. 178; Végh-Neubrandt 1973, p. 297; Oravecz 1987, p. 3, fig. 6; Haas 2002, p. 170; Haas et al. 2005, p. 517); Cordilleranus and/or Amoenum Zones.

Loc. 32 - Hallstatt Limestone, Silická Brezová, Slovakian Karst, Western Carpathians, Slovakia (Kochanová and Kollárová-Andrusovová 1983, p. 577, pl. 12, figs 3, 6, 7, 9); Cordilleranus Zone.

Loc. 33 - Monotis-bearing Hallstatt-type limestone, Ciungi-Timon olistolith, Fundu Moldovei, Eastern Carpathians, Romania (Grădinaru and Sobolev, this paper); Cordilleranus Zone.

Loc. 34 - Glogova Formation, Luda Kamchia Zone, Kotel, Balkans, Bulgaria (SachariewaKowatschewa 1967, p. 76, pl. 5, fig. 9); Cordilleranus and/or Amoenum Zones.

Most of the above-listed occurrences of Rhabdoceras suessi are from the northern margin or central part of the western Tethys, such as those from the Northern Calcareous Alps, Carpathians and Balkans, and the Hungarian Transdanubian Range; only the occurrence from the Panormide Carbonate Platform in Sicily are from the southern part. 
Central Asia. East of an extended gap in its occurrence in the Tethyan regions of Middle Asia, various morphotypes of Rhabdoceras are known from the Upper Norian of the Pamirs (Fig. 6, Loc. 35).

Loc. 35 - Monotis salinaria beds, southeastern Pamirs, Tajikistan (Kushlin 1965, 1966; Shevyrev 1990, p. 137, pl. 8, fig. 1; Shevyrev 2001, p. 144, text-fig. 23, pl. 61, fig. 6a-c); Quinquepunctatus Zone (= Cordilleranus Zone).

In the southeastern Pamirs Rhabdoceras suessi is reported from a limy-marly sequence in the upper part of the Aktash Series, including several isochronous formations (Nayzatash, Igrimyuz and Kamarutek Formations), where it cooccurs with Monotis salinaria, Heterastridium conglobatum and ammonoids indicative of the Upper Norian Sagenites quinquepunctatus Zone (Shevyrev 2001; Dronov 2001). The other two morphotypes of the genus Rhabdoceras are included in the same ammonoid assemblage, Rhabdoceras curvatum Mojsisovics and Rhabdoceras laeve, the last species being originally described in this region by Kushlin (1965/1966). The occurrence of Rhabdoceras representatives in the Pamirs is as yet the only one reported in shelf deposits on the northern rim of the NeoTethys, which was inhabited by low-paleolatitude faunas.

Southeast Asia. The easternmost occurrences of Rhabdoceras are in Misool and Timor islands, in southeastern part of the Indonesian Archipelago (Fig. 6, Locs 36-38).

Loc. 36 - Nucula Marl/Lios Member, Bogal Formation, Misool Island, Moluccan Archipelago, eastern Indonesia (Wanner 1910, p. 739; Jaworski 1915, p. 133, pl. 45, figs 14-15; Campbell and GrantMackie 2000, p. 249; Hasibuan 2008, p. 324; Hasibuan 2010, pp. 36, 43, fig. 1); Amoenum Zone.

Loc. 37 - Hallstatt Limestone, Noe Bihati (Baun), West Timor, eastern Indonesia (Tatzreiter 1981, p. 13); Cordilleranus Zone.

Loc. 38 - Gray Limestone of Aliambata, Timor-Leste (East Timor) (Tozer 1971, p. 1020; Tozer 1980c, p. 855); Cordilleranus Zone.

Misool Island is located in the northern Banda Arc province, where the Triassic rocks are included in the para-autochthonous sequence of the Salawati Basin, while Timor Island is located in the forearc of the southern Banda Arc province, both of these tectonostratigraphic provinces being interpreted as belonging to Gondwanan eastern Indonesia (e.g. Charlton 2001). The occurrence of Rhabdoceras suessi in West Timor, within an extremely rich Tethyan-type ammonoid assemblage along with the planktonic hydrozoan Heterastridium, is in a Hallstatt-type condensed limestone, occurring as isolated blocks in the so-called Allochthonous Series of Sonnebait, which is included in the tectonic mélange of the accretionary prism of the Banda Arc (Martini et al. 2000). The allochthonous pelagic Triassic of Timor, which facially is definitely distinct from that of the Australian margin, represents obducted remnants of Hallstatt-topped seamounts littered in the south-eastern Tethys Seaway, where it reached the Panthalassa Ocean. The occurrence of M. (Pacimonotis) subcircularis in Upper Norian strata in several microcontinents (Seram, Timor, Roti, etc.) in eastern Indonesia (Campbell and Grant-Mackie 2000) supports their emplacement at a southern, approximately $30^{\circ}$ Triassic paleolatitude in the eastern part of Gondwanaland, a 
conclusion that is also supported by the paleobiogeographic signature of the Upper Triassic corals from Timor-Leste (East Timor) (Roniewicz et al. 2005, fig. 9).

\section{Paleoecology}

In the eastern part of Panthalassa (paleo-Pacific Ocean), Rhabdoceras is found in pelagic assemblages, along with thin-shelled monotid bivalves and the planktonic hydrozoan Heterastridium, in Cordilleranus Zone deposits on the North American craton margin, and also in many oceanic island arcs. Cratonbound, or craton-related deposits of this age include those from the Great Basin in western Nevada, and especially those of the Pardonet Formation in the Rocky Mountain Foothills of western Canada, from where the most abundant occurrences of this heteromorphic ammonoid are known, in open-marine deposits (Tozer 1970, 1982a, 1994a). On the other hand, the occurrences of Rhabdoceras in the Amoenum Zone (Cassianella Beds in southern British Columbia, the Arenaceous Member of Parson Bay Formation in Vancouver Island, and the Nun Mine Member of the Gabbs Formation in the New Canyon, western Nevada), in the Crickmayi Zone (Sutton Formation in Vancouver Island, and in the Antimonio Formation in Mexico) are all in benthos-related assemblages (Tozer 1970, 1994a; Laws 1982; Gonzáles et al. 2000), with their most notable abundance being in the Gabbs Formation in western Nevada. Comparable pelagic and benthos-related biofacies are those from the Cordilleranus and Amoenum Zones in the Pacific Cordillera of South America, such as of the Payandé Formation from the "Oriente Andino" in Colombia (Geyer 1979) and of the Aramachay Formation from the Pucará Basin in Peru (Stanley 1994), and also of the Privalninsky Formation in Western Chukotka (Bychkov and Solov'ev 1992). Faunal facies changing from pelagic in the Upper Norian to benthos-dominated in the Rhaetian reflects an upward marine shallowing during the end-Triassic in northern Circum-Panthalassa (e.g. Laws 1982; Taylor et al. 1983; González-León et al. 1995; Hallam and Wignall 2000; Lucas et al. 2007).

In the western Tethys, as known from Austrian Northern Calcareous Alps, Rhabdoceras inhabited various pelagic and benthonic biotopes: on the outer slope of Bahamian-type Dachstein carbonate platforms, in mixed intraplatform Kössen basins, in Hallstatt facies on pelagic carbonate plateaus, and in marly Zlambach basins, in autochthonous/para-autochthonous assemblages (Zapfe 1967b; Wiedmann 1972, 1973, 1974; Krystyn 1991; Krystyn et al. 2009). Similar biotopes are also found in Sicily, the Hungarian Transdanubian Range, the Carpathians, the Balkans, the Pamir Mts and in southeastern Indonesia. The reported occurrences in fissure-fillings in both Dachstein and Hallstatt Limestone in the Alps must be interpreted as incidental, and not as a normal habitat as inferred by some authors (e.g. Hornung 2005).

As regards the life habits and feeding modes of the Late Triassic heteromorphic ammonoids, they are interpreted as either planktonic or benthic animals (Tozer 1970, 1994a; Wiedmann 1973, 1974; Laws 1982; Wang and Westermann 1993; 
Shevyrev 2005). There is compelling evidence that the end-Triassic regressive trend had led the heteromorphic ammonoids to change, after the Late Norian, from a planktonic to an epibenthic scavenger-micropredator habit, which is demonstrated by the Rhaetian trophic nucleus in the Gabbs Formation in western Nevada (Laws 1982).

\section{Conclusions}

The occurrence of the heteromorphic ammonoid Rhabdoceras suessi is for the first time reported here from the Romanian Carpathians, and this record fills a gap in our current knowledge on the distribution of this ammonoid in the Western Tethyan regions.

As shown in the present paper, in the second part of the 1970s Rhabdoceras suessi held a privileged position among the uppermost Triassic ammonoids, being nominated and used in North America and Europe as the index fossil of the former Upper Norian Suessi Zone (= Rhabdoceras suessi Zone). The remarkable achievements in North American Triassic biostratigraphy that resulted from the outstanding studies carried out by Tozer during second half of 20th century, deposed this ammonoid from its status as an index taxon by the end of the 1970s. A coincident controversial dispute about the status of the Rhaetian as a stage arose during the 1980s. The achievements resulting from studies in the Austrian Alps have reinstalled the Rhaetian as the topmost stage of the Triassic, its base now having a biostratigraphically well-documented standard stratotype. The history of the long debated bio- and chronostratigraphy of the uppermost Triassic is a lesson from which stratigraphers must learn that only a general consensus based on objective data in biostratigraphically well-calibrated stratotypes can contribute to the continuous and endless work to improve the Triassic timescale, bearing in mind at all times that the biostratigraphic record is imperfect and incomplete by its very nature.

Biogeographically, the heteromorphic ammonoid Rhabdoceras suessi is a pandemic, long-ranging Late Norian and Rhaetian ammonoid widely dispersed in the low- and mid-paleolatitude faunas of western North and South America, Alpine Europe, Pamirs and southeast Indonesia. The heteromorphic ammonoid Rhabdoceras suessi is suitable for worldwide correlations only when it occurs together with age-diagnostic, short-range choristoceratids, or with monotid bivalves and the hydrozoan Heterastridium.

The distribution of present-day occurrences of Rhabdoceras suessi, together with contemporaneous biotas, shows an intriguingly broad latitudinal range in the Western Cordillera of North America, not representative of their original Late Triassic paleobiogeography. The various allochthonous tectonostratigraphic terranes where this ammonoid occurs were dispersed in the tropical/subtropical belt of eastern Panthalassa, subsequently accreted to and tectonically displaced northward by large-scale post-Triassic faulting to higher latitudes along the 
disrupted Mesozoic margin of the North American craton. This Late Triassic ammonoid, along with other coeval fossil assemblages, contributed to the deciphering of the terrane puzzle of the North American Cordillera, and also of other regions, such as Northeast Asia. Triassic biotas appear especially useful for the biogeographic interpretation and paleogeographic analyses of the accreted terranes of the North American Cordillera. The utility of the Triassic fossils for fueling and testing paleogeographic and tectonic hypotheses has greatly contributed to the emerging and growing concepts of the exotic or displaced terrane theory, which in turn helped to explain the anomalies of their actual occurrences.

\section{Acknowledgements}

First of all, we owe thanks to Thomas Hofmann, Head of Bibliothek and Verlag, Geologische Bundesanstalt, Wien, who graciously provided many of the references used in the present paper. Our thanks are also extended to Platon Tchoumatchenco in Sofia, Olga Piros of MÁFI in Budapest, and Daniela Vlad from Shell Canada in Calgary, who helped us with Bulgarian, Hungarian and Canadian references, respectively. We address special thanks to Norman Silberling, Lakewood, Colorado, for fruitful correspondence and for providing valuable insight toward our understanding of the North American terrane tectonics, he being one of the most outstanding founders of the concept of terrane tectonics, to the deciphering of which he magisterially contributed. We also thank him for his thoughtful review and improving of our manuscript. The paper has benefited greatly of the remarkable Triassic knowledge of Leo Krystyn, Vienna, whose thorough review improved the manuscript. We gratefully acknowledge Robert B. Blodgett, Anchorage, Alaska, for encouraging us and for his constructive comments that substantially improved our paper. We are also grateful to Paul Smith, Vancouver, for offering us details on the Rhabdoceras occurrence on the Alaska Peninsula. József Pálfy, the topic editor for paleontology and stratigraphy at the Central European Geology journal, is thanked for constructive suggestions and comments. The invitation given to us by János Haas, the editor of the CEG volume devoted to the memory of Sándor Kovács, to contribute to this volume is highly appreciated by the first author who shared a long-lasting and sincere friendship with Sanyi. This research was financially supported in Romania by the CNCSIS Project 1669/2007. 


\section{References}

*** 1987: The Rhaetian controversy: 1978-1988. - Albertiana, p. 13.

Afitsky, A.I. 1965: The first discovery of Rhabdoceras in the north-eastern USSR. - Paleontological Journal, U. S. S. R. Academy of Sciences, 3, pp. 137-138. (In Russian.)

Afitsky, A.I. 1966: First discovery of Rhabdoceras in northeastern U. S. S. R. - International Geology Review, 8/7, pp. 842-843.

Afitsky, A.I. 1970: Biostratigraphy of the Triassic and Jurassic deposits of the basin of the Bol'shoy Anyuy River Basin (Western Chukotka). - Transactions of Scientific Research Institute, North East Complex, 26, 148 p. (In Russian.)

Ager, D. 1987: A defence of the Rhaetian stage. - Albertiana, 6, pp. 6-13.

Ager, D. 1988: Dogmatism versus pragmatism in the Rhaetian stage. - Albertiana, p. 16.

Ager, D. 1990: Rhaetian reconciliation. - Albertiana, 8, pp. 8-9.

Antonelli, M., R. Franciosi, G. Pezzi, A. Querci, G.P. Ronco, F. Vezzani 1992: Formazione Sciacca. Carta Geologica d'Italia 1:50.000 - Catalogo delle Formazioni, APAT - Dip. Scienze della Terra, Univ. di Firenze - Commissione Italiana di Stratigrafia, pp. 163-173.

Arthaber, G. von 1906: Die alpine Trias des Mediterran-Gebietes. - In: F. Frech (Ed.): Lethaea Geognostica, II, Das Mesozoikum, Bd. I, Trias (3). E. Schweizerbart'schen Verlagshandlung, Stuttgart, pp. 223-391, 417-472.

Balini, M., S.G. Lucas, J.F. Jenks, J.A. Spielman 2010: Triassic ammonoid biostratigraphy: an overview. - In: Lucas, S.G. (Ed.): The Triassic Timescale. - Geological Society, London, Special Publication, 334, pp. 221-262.

Blodgett, R.B. 2008: Paleontology and stratigraphy of the Upper Triassic Kamishak Formation in the Puale Bay-Cape Kekurnoi-Alinchak Bay area, Karluk C-4 and C-5 quadrangle, Alaska Peninsula. - In: Reifenstuhl, R.R., P.L. Decker (Eds): Bristol Bay-Alaska Peninsula region, overview of 2004-2007 geologic research. - Alaska Division of Geological and Geophysical Surveys Report of Investigation, 2008-1H, pp. 131-160.

Blodgett, R.B., K.H. Clautice 2000: Fossil locality map for the Healy A-6 Quadrangle, south-central Alaska. - Alaska Division of Geological and Geophysical Surveys Report of Investigations 2000-5, 42 p.

Blodgett, R.B., J. Frýda 2001a: Upper Triassic gastropod biogeography of western North America. Geological Society of America Abstracts with Programs, 33/3, p. A-53.

Blodgett, R.B., J. Frýda 2001b: On the occurrence of Spinidelphinulopsis whaleni (Gastropoda) in the Late Triassic (early Norian) Cornwallis Limestone, Kuiu Island, southeastern Alaska (Alexander terrane) and its paleobiogeographic significance. - Bulletin of the Czech Geological Society, 76/4, pp. 235-242.

Blodgett, R.B., J. Frýda, G.D. Stanley Jr. 2001: Delphinulopsidae, a new neritopsoidean gastropod family from the Upper Triassic (upper Carnian or lower Norian) of the Wallowa terrane, northeastern Oregon. - Journal of the Czech Geological Society, 46/1, pp. 221-232.

Blodgett, R.B., G.D. Stanley Jr. 2008: Introduction. - In: Blodgett, R.B., G.D. Stanley Jr. (Eds): The terrane puzzle: new perspectives on paleontology and stratigraphy from the North American Cordillera. - The Geological Society of America, Special Paper, 442, pp. V-VIII.

Boltz, H. 1974: Die Zlambach-Schichten (alpine Obertrias) unter besonderer Berücksichtigung der Ostrakoden, 2: Zur Stratigraphie und Fazies der Zlambach-Schichten. - Senckenbergiana Lethaea, 55 (1/5), pp. 325-361.

Bychkov, Yu.M. 2000: Upper Triassic Biostratigraphy and Faunas in Northeast Asia. - In: Gagiev, M.H., O.N. Ivanov (Eds): The Sketches on Stratigraphy of Northeastern Asia: A Collection of Scientific Papers, NEISRI FEB RAS, Magadan, pp. 98-110. (In Russian.)

Bychkov, Yu.M., G.I. Solov'ev 1992: New data on the stratigraphy and lithology of Triassic deposits of the Bol'shoy Anyui River. - In: Pokhialainen, V.P. (Ed.): Lower Mesozoic of the right bank of the Kolyma River. SVKNII, Ministry of Geology, Magadan, pp. 3-24. (In Russian.) 
Campbell, H.J., J.A. Grant-Mackie 2000: The Marine Triassic of Australasia and its interregional correlation. - In: Yin, H., J.M. Dickins, G.R. Shi, J. Tong (Eds): Permian-Triassic Evolution and Western Circum-Pacific. - Developments in Paleontology and Stratigraphy, 18, pp. 235-255.

Carter, E.S. 1990: New Biostratigraphic Elements for dating Upper Norian Strata from the Sandilands Formation, Queen Charlotte Islands, British Columbia, Canada. - Marine Micropaleontology, 15, pp. 313-328.

Carter, E.S. 1993: Biochronology and Paleontology of uppermost Triassic (Rhaetian) radiolarians, Queen Charlotte Islands, British Columbia, Canada. - Mémoires de Géologie, 11, 132 p.

Carter, E.S., M.J. Orchard, E.T. Tozer 1989: Integrated ammonoid-conodont-radiolarian biostratigraphy, Late Triassic Kunga Group, Queen Charlotte Islands, British Columbia. Current Research, Part H, Geological Survey of Canada, Paper 89-1H, pp. 23-30.

Carter, E.S., M.J. Orchard, C.A. Ross, J.R.P. Ross, P.L. Smith, H.W. Tipper 1991: Paleontological signatures of terranes. - In: Gabrielse, H., C.J. Yorath (Eds): Geology of the Cordilleran Orogen in Canada. - Geological Survey of Canada, Geology of Canada, 4, pp. 28-38.

Carter, E.S., M.J. Orchard 2007: Radiolarian - conodont - ammonoid intercalibration around the Norian-Rhaetian Boundary and implications for trans-Panthalassan correlation. - Albertiana, 36, pp. 149-163.

Caruthers, A.H., G.D. Stanley Jr. 2008: Late Triassic silicified shallow-water corals and other marine fossils from Wrangellia and the Alexander terrane, Alaska, and Vancouver Island, British Columbia. - In: Blodgett, R.B., G.D. Stanley Jr. (Eds): The terrane puzzle: new perspectives on paleontology and stratigraphy from the North American Cordillera. - The Geological Society of America, Special Paper, 442, pp. 151-179.

Catalano, R., B. D'Argenio, G. Lo Cicero 1974: Ritmi depozitionali e processi diagenetici nella successione triasica di piattaforma carbonatica dei Monti di Palermo. - Bolletino della Società Geologica Italiana, 93/4, pp. 1029-1041.

Charlton, T.R. 2001: Permo-Triassic evolution of Gondwanan eastern Indonesia, and the final Mesozoic separation of SE Asia from Australia. - Journal of Asian Earth Sciences, 19, pp. 595-617.

Coney, P.J., D.L. Jones, J.W.H. Monger 1980: Cordilleran suspect terranes. - Nature, 288, pp. 329-333.

Dagys, A. 1988: An alternative interpretation of the Rhaetian. - Albertiana, 7, pp. 4-6.

Dagys, A.S., A.A. Dagys 1994: Global correlation of the terminal Triassic. - In: Guex, J., A. Baud: Recent developments on Triassic stratigraphy (Proceedings of the Triassic Symposium, Lausanne, 20-25 Oct. 1991). - Mémoires de Géologie (Lausanne), 22, pp. 25-34.

Dalziel, I.W.D., R.D. Forsythe 1985: Andean Evolution and the Terrane Concept. - In: Howell, D.G. (Ed.): Tectonostratigraphic Terranes of the Circum-Pacific Region, Circum-Pacific Council for Energy and Mineral Resources. - Earth Science Series, 1, pp. 565-581.

Detterman, R.L. 1988: Mesozoic biogeography of southern Alaska, with implications for the paleogeography: - U.S. Geological Survey Open-File Report 88-662, 27 p.

Detterman, R.L., J.E. Case, J.W. Miller, F.H. Wilson, M.E. Yount 1996: Stratigraphic Framework of the Alaska Peninsula. - U. S. Geological Survey Bulletin 1969-A, 74 p.

Dickinson, W.R. 2004: Evolution of the North American Cordillera. - Annual Review of Earth and Planetary Sciences, 32, pp. 13-45.

Dickinson, W.R., P.N. Swift, P.J. Coney 1986: Tectonic strip maps of the Alpine-Himalaya and CircumPacific Orogenic belts (great circle projections). - Geological Society of America, Map Chart Series MC-58, Scale 1:20,000,000.

Diener, C. 1915: Cephalopoda Triadica. - In: F. Frech (Ed.): Fossilium Catalogus, I Animalia, Pars 9. W. Junk, Berlin, 369 p.

Diener, C. 1925: Leitfossilien der Trias, Wirbellose Tiere und Kalkalgen. - In: Gürich, G. (Ed.): Leitfossilien. Verlag von Gebrüder Borntraeger, Berlin, 104 p.

Dronov, V.I. 2001: Stratigraphy. - In: Rozanov, A.Yu., A.A. Shevyrev (Eds): Atlas of Triassic invertebrates from Pamir. Nauka, Moskva. pp. 5-29. (In Russian.)

Dronov, V.I., G.K. Melnikova, E.B. Paevskaia, A.A. Shevyrev 1982: On the age of the Igrimiuz suite.Doklady Akademii Nauk SSSR, V/267 (5), pp. 1181-1182. (In Russian.) 
Frýda, J., R.B. Blodgett 2003: Silberlingiella, a new purpurinid genus (Littorinoidea, Gastropoda) from the late middle Norian (Late Triassic) of the Clan Alpine Range, western Nevada. Mitteilungen des Geologisch-Paläontologischen Instituts der Universität Hamburg, 87, pp. $47-54$.

Gabrielse, H., J.W.H. Monger, J.O. Wheeler, C.J. Yorath 1991: Morphological belts, tectonic assemblages and terranes. - In: Gabrielse, H., C.J. Yorath (Eds): Geology of the Cordilleran Orogen in Canada. - Geological Survey of Canada, Geology of Canada, 4, pp. 15-28.

Gallet, Y., J. Besse, L. Krystyn, J. Marcoux 1996: Norian magnetostratigraphy from the Scheiblkogel section, Austria: constraint on the origin of the Antalya Nappes, Turkey. - Earth and Planetary Science Letters, 140, pp. 113-122.

Gallet, Y., L. Krystyn, J. Besse, J. Marcoux 2003: Improving the Upper Triassic numerical time scale from cross-correlation between Tethyan marine sections and the continental Newark basin sequence. - Earth and Planetary Science Letters, 212, pp. 255-261.

Gallet, Y., L. Krystyn, J. Marcoux, J. Besse 2007: New constraints on the End-Triassic (Upper Norian-Rhaetian) magnetostratigraphy. - Earth and Planetary Science Letters, 255, pp. $458-470$.

Gazdzicki, A., H. Kozur, R. Mock 1979: The Norian-Rhaetian boundary in the light of micropaleontological data. - Geologija, 22/1, pp. 71-112.

Gemmellaro, G.G. 1904: I Cefalopodi del Trias superior della regione occidentale della Sicilia. Giornale di Scienze Naturali ed Economiche, Palermo, 24, pp. 1-319.

Gemmellaro, M. 1923: Il "Trias" dei dintorni di Palermo. - Giornale di Scienze Naturali ed Economiche, Palermo, 33, pp. 127-209.

Geyer, O.F. 1973: Das präkretazische Mesozoikum von Kolumbien. - Geologisches Jahrbuch, B 5, $165 \mathrm{p}$.

Geyer, O.F. 1979: Zur Paläogeographie mesozoischer Ingressionen und Transgressionen in Kolumbien. - Neues Jahrbuch für Geologie und Paläontologie Monatshefte, 6, pp. 349-368.

Golebiowski, R. 1986: Neue Misikellen-Funde (Conodonta) und ihre Bedeutung für die Abgrenzung des Rhät s.str. in den Kössener Schichten. - Sitzungsberichte der Österreichischen Akademie der Wissenschaften, Mathematisch-Naturwissenschaftliche Klasse, Abt. 1, 195/1-5, pp. 53-65.

Golebiowski, R. 1990: The Alpine Kössen Formation. A key for European topmost Triassic correlations. A Sequence- and Ecostratigraphic Contribution to the Norian-Rhaetian Discussion. - Albertiana, 8, pp. 25-35.

González-León, C.M., D.G. Taylor, G.D. Stanley Jr. 1995: The Antimonio Formation in Sonora, Mexico, and the Triassic-Jurassic boundary. - Canadian Journal of Earth Sciences, 33, pp. $418-422$.

González-León, C.M., G.D. Stanley Jr., D.G. Taylor 2000: Ammonoid discoveries in the Antimonio Formation, Sonora, Mexico: new constraints on the Triassic-Jurassic boundary. - Journal of South American Earth Sciences, 13, pp. 491-497.

Goodwin, D.H., G.D. Stanley Jr. 1997: Norian sponge and coral biostromes in the Antimonio Formation, northwestern Sonora, Mexico. - Revista Mexicana de Ciencias Geológicas, 14/2, pp. 160-166.

Grant-Mackie, J.A. 1985: The Warepan Stage of the Upper Triassic: redefinition and subdivision. New Zealand Journal of Geology and Geophysics, 28, pp. 701-724.

Grant-Mackie, J.A., N.J. Silberling 1990: New data on the Upper Triassic bivalve Monotis in North America, and the new subgenus Pacimonotis. - Journal of Paleontology, 64/2, pp. 240-254.

Haas, J. 2002: Origin and evolution of Late Triassic backplatform and intraplatform basins in the Transdanubian Range, Hungary. - Geologica Carpathica, 53/3, pp. 159-178.

Haas, J., T. Budai, I. Szente, O. Piros, E. Tardiné Filácz 2005: Upper Triassic slope and basin sequences in the Pilis Mts and the Tatabánya Basin. - Földtani Közlöny, 135/4, pp. 513-543. (In Hungarian, with English summary.)

Haggart, J.W., R.J. Enkin, J.W.H. Monger 2006: Strenghts and limitations of paleogeographic methods in assessing large-scale displacements within the North American Cordillera. - In: 
Haggart, J.W., R.J. Enkin, J.W.H. Monger (Eds): Paleogeography of the North American Cordillera: Evidence For and Against Large-Scale Displacements. - Geological Association of Canada Special Paper, 46, pp. 1-11.

Hallam, A., P.B. Wignall 2000: Facies changes across the Triassic-Jurassic boundary in Nevada, USA. - Journal of the Geological Society, London, 157, pp. 49-54.

Hasibuan, F. 2008: Pre-Tertiary Biostratigraphy of Indonesia. - In: Proceedings of the International Symposia on Geoscience Resources and Environments of Asian Terranes (GREAT 2008), 4th IGCP 516, and 5th APSEG; November 24-26, Bangkok, Thailand, pp. 323-325.

Hasibuan, F. 2010: The Triassic Marine Biota of Eastern Indonesia and its Interregional and Global Correlation: A Review. - Jurnal Geologi Indonesia, 5/1, pp. 31-47.

Hauer, F von 1860: Nachträge zur Kenntniss der Cephalopoden-Fauna der Hallstätter Schichten. Sitzungsberichte der Akademie der Wissenschaften in Wien (1), 41, pp. 113-150.

Hillebrandt, A. von 1990: The Triassic/Jurassic boundary in Northern Chile. - Cahiers de l'Université Catholique de Lyon, série Science, 3, pp. 27-53.

Hillebrandt, A. von 1994: The Triassic/Jurassic boundary and Hettangian Biostratigraphy in the Area of the Utcubamba Valley (Northern Peru). - Geobios, 27, suppl. 2, pp. 297-307.

Hornung, T. 2005: Paleoclimate background and stratigraphic evidence of Late Norian/Early Rhaetian polyphase synsedimentary tectonics in the Hallstatt Limestones of Berchtesgaden (Rappolstein, Southern Germany). - Austrian Journal of Earth Sciences, 98, pp. 106-119.

Howarth, M.K. 1981: Paleogeography of the Mesozoic. - In: Greenwood, P.H. (Ed.): The Evolving Earth. Cambridge University Press, pp. 197-220.

Howell, D.G., D.L. Jones, E.R. Schermer 1985: Tectonostratigraphic Terranes of the Circum-Pacific Region. - In: Howell, D.G. (Ed.): Tectonostratigraphic Terranes of the Circum-Pacific Region, Circum-Pacific Council for Energy and Mineral Resources. - Earth Science Series, 1, pp. 3-30.

Hyatt, A. 1892: Jura and Trias at Taylorville, California. - Geological Society of America Bulletin, 3, pp. 395-412.

Hyatt, A., J.P. Smith 1905: The Triassic cephalopod genera of America. - U. S. Geological Survey Professional Paper 40, $394 \mathrm{p}$.

Iordan, M. 1978: The Triassic brachiopods from the Rarău Syncline and the Perşani Mountains areas. - Dări de seamă ale Şedinţelor, Institutul Geologic şi Geofizic, 64/3, pp. 69-84.

Iordan, M. 1993: Triassic brachiopods of Romania. - In: Pálfy, J., A. Vörös (Eds): Mesozoic brachiopods of Alpine Europe. - Proceedings of the Regional Field Symposium on Mesozoic Brachiopods, Vörösberény, Hungary, 6-11 September, 1992, Hungarian Geological Society, pp. $49-58$.

Irving, E. 1979: Pole positions and continental drift since the Devonian. - In: McElhinny, M.W. (Ed.): The Earth: its origin, structure, and evolution. Academic Press, London, pp. 567-593

Janensch, W. 1906: Ueber die Jugendentwicklung von Rhabdoceras Suessi v. Hauer. - Centralblatt für Mineralogie, Geologie und Paläontologie, Jahrgang 1906, pp. 710-716.

Jaworski, E. 1915: Die Fauna der obertriadische Nucula-Mergel von Misol. - Paläontologie von Timor II (5), pp. 71-174.

Jaworski, E. 1923: Die marine Trias in Südamerika. - Neues Jahrbuch für Mineralogie, Geologie und Paläontologie, Beilage-Band, 47, pp. 93-200.

Jones, D.L., D.G. Howell, P.J. Coney, J.W.H. Monger 1983: Recognition, character, and analysis of tectonostratigraphic terranes in western North America. - In: Hashimoto, M., S. Ueda (Eds): Accretion tectonics in the Circum-Pacific region. Advances in Earth and Planetary Sciences. Terra Scientific Publishing Company, Tokyo, pp. 21-35.

Jones, D.L., N.J. Silberling, P.J. Coney 1986: Collision tectonics in the Cordillera of western N America: examples from Alaska. - In: Coward, M.P., A.C. Ries (Eds): Collision tectonics. Geological Society, London, Special Publication, 19, pp. 367-387.

Jones, D.L., N.J. Silberling, P.J. Coney, G. Plafker 1987: Lithotectonic terrane map of Alaska (west of the 141st Meridian). - U.S. Geological Survey Miscellaneous Field Studies, Map MF-1874-A, 1 sheet, scale 1:2,500,000. 
Katvala, E.C., G.D. Stanley Jr. 2008: Conodont biostratigraphy and facies correlations in a Late Triassic island arc, Keku Strait, southeast Alaska. - In: Blodgett, R.B., G.D. Stanley Jr. (Eds): The terrane puzzle: new perspectives on paleontology and stratigraphy from the North American Cordillera. - The Geological Society of America, Special Paper 442, pp. 181-226.

Kittl, E. 1903: Geologische Exkursionen im Salzkammergut (Umgebung von Ischl, Hallstatt und Aussee). IX. Internationaler Geologen-Kongress, Exkursionen in Oesterreich. GesellschaftsBuchdruckerei Brüder Hollinek, Wien. Exkursionsführer IV, 118 p.

Kochanová, M., V. Kollárová-Andrusovová 1983: Obertriassische Bivalven und Ammonoideen der westlichen Umgebung von Silická Brezová (Slowakischer Karst, Westkarpaten). - Geologica Carpathica, 34/5, pp. 535-590.

Kollárová-Andrusovová, V. 1983: Obertriassische Heterastridien (Hydrozoa) in den Westkarpaten. Geologica Carpathica, 34/2, pp. 151-186.

Kozur, H. 1973: Beiträge zur Stratigraphie und Paläontologie der Trias. - GeologischPaläontologische Mitteilungen Innsbruck, 3/1, pp. 1-30.

Kozur, H. 2003a: Integrated ammonoid, conodont and radiolarian zonation of the Triassic and some remarks to Stage/Substage subdivision and the numeric age of the Triassic stages. - Albertiana, 28 , pp. $57-74$.

Kozur, H. 2003b: Integrated ammonoid, conodont and radiolarian zonation of the Triassic. Hallesches Jahrbuch für Geowissenschaften, B 25, pp. 49-79.

Krystyn, L. 1973: Zur Ammoniten- und Conodonten-Stratigraphie der Hallstätter Obertrias (Salzkammergut, Österreich). - Verhandlungen der Geologischen Bundesanstalt, 1, pp. 113-153.

Krystyn, L. 1974: Probleme der biostratigraphischen Gliederung der Alpin-Mediterranen Obertrias. - Schriftenr. Erdwiss. Komm. Österr. Akad. Wiss., 2, pp. 137-144.

Krystyn, L. 1980: Stratigraphy of the Hallstatt region. - In: Krystyn L., B. Plöchinger, H. Lobitzer (Eds): Field Trip B, Triassic conodont localities of the Salzkammergut region. - Abhandlungen der Geologischen Bundesanstalt, 35, pp. 69-98.

Krystyn, L. 1988: Zur Rhät-Stratigraphie in den Zlambach-Schichten (vorläufiger Bericht). Sitzungsberichte der Österreichischen Akademie der Wissenschaften, MathematischNaturwissenschaftliche Klasse, 196/3 (1987), pp. 21-36.

Krystyn, L. 1990: A Rhaetian stage-chronostratigraphy, subdivisions and their intercontinental correlation. - Albertiana, 8, pp. 15-24.

Krystyn, L. 1991: Die Fossillagertätten der alpine Trias. - In: Vasicek, V., L. Krystyn, R. Golebiowski (Eds): Exkursion im Jungpaläozoikum und Mesozoikum Österreichs. Österr. Paläont. Ges., pp. 23-78.

Krystyn, L. 2008a: An ammonoid-calibrated Tethyan conodont time scale of the late Upper Triassic. In: Krystyn, L., G.W. Mandl (Eds): Upper Triassic Subdivisions, Zonations and Events. Abstracts and Excursion-Guide. - Berichte der Geologischen Bundesanstalt, 76, pp. 9-11.

Krystyn, L. 2008b: The Hallstatt pelagics - Norian and Rhaetian Fossillagerstaetten of Hallstatt. - In: Krystyn, L., G.W. Mandl (Eds): Upper Triassic Subdivisions, Zonations and Events. Abstracts and Excursion-Guide. - Berichte der Geologischen Bundesanstalt, 76, pp. 81-98.

Krystyn, L., G. Schäffer, W. Schlager 1971: Über die Fossil-Lagerstätten in den triadischen Hallstätter Kalken der Ostalpen. - Neues Jahrbuch für Geologie und Paläontologie, Abhandlungen, 137/2, pp. 284-304.

Krystyn, L., J. Wiedmann 1986: Ein Choristoceras-Vorläufer (Ceratitina, Ammonoidea) aus dem Nor von Timor. - Neues Jahrbuch für Geologie und Paläontologie, Monatshefte, 1, pp. 27-37.

Krystyn, L., W.E. Piller 2000: Austria as the World Famous Window to Triassic Tropical Sealife. Mitteilungen der Österreichischen Geologischen Gesellschaft, 92, pp. 204-208.

Krystyn, L., W. Kuerschner 2005: Biotic events around the Norian - Rhaetian boundary from a Tethyan perspective. - Albertiana, 32, pp. 17-20.

Krystyn, L., H. Bouquerel, W. Kuerschner, S. Richoz, Y. Gallet 2007a: Proposal for a candidate GSSP for the base of the Rhaetian Stage. - In: Lucas S.G., J.A. Spielmann (Eds): The Global Triassic. New Mexico Museum of Natural History and Science Bulletin, 41, pp. 189-199.

Central European Geology 53, 2010 
Krystyn, L., S. Richoz, Y. Gallet, H. Bouquerel, W.M. Kürschner, C. Spötl 2007b: Updated bio- and magnetostratigraphy from Steinbergkogel (Austria), candidate GSSP for the base of the Rhaetian stage. - Albertiana, 36, pp. 164-173.

Krystyn, L., G.W. Mandl, M. Schauer 2009: Growth and termination of the Upper Triassic platform margin of the Dachstein area (Northern Calcareous Alps, Austria). - Austrian Journal of Earth Sciences, 102, pp. 23-33.

Kummel, B. 1957: Suborder Ceratitina Hyatt, 1884. - In: Moore, R.C. (Ed.): Treatise on Invertebrate Paleontologie, Part L, Mollusca 4, Cephalopoda, Ammonoidea. Univ. Kansas Press, pp. 130-185.

Kushlin, B.K. 1965: Straight ammonoids from the Triassic of the Pamirs. - Paleontological Journal, U. S. S. R. Academy of Sciences, 3, pp. 139-141. (In Russian.)

Kushlin, B.K. 1966: Straight ammonoids from Pamir Triassic. - International Geology Review, 8/7, pp. 844-847.

Kutassy, A. 1927: Beiträge zur Stratigraphie und Paläontologie der alpinen Triasschichten in der Umgebung von Budapest. - Jahrbuch der königlich ungarischen Geologischen Anstalt, 27/2, pp. 105-176.

Kutassy, A. 1932: Cephalopoda triadica II. - In: Quenstedt, W. (Ed.): Fossilium Catalogus, I Animalia, Pars 56. W. Junk, Berlin, $832 \mathrm{p}$.

Kutassy, A. 1936: Faunen aus dem Hauptdolomit und Dachsteinkalk des Budaer Gebirges. Mathematischer und Naturwissenschaftlicher Anzeiger der ungarischen Akademie der Wissenschaften, 54/3, pp. 1006-1050.

Laws, R.A. 1982: Late Triassic depositional environments and molluscan associations from westcentral Nevada. - Palaeogeography, Palaeoclimatology, Palaeoecology, 37, pp. 131-148.

Lucas, S.G. 2010: The Triassic timescale: an introduction. - Geological Society, London, Special Publications, 334, pp. 1-16.

Lucas, S.G., D.G. Taylor, J. Guex, L.H. Tanner, K. Krainer 2007: The proposed global stratotype section and point for the base of the Jurassic System in the New York Canyon area, Nevada, USA. - In: Lucas, S.G, J.A. Spielmann (Eds): The Global Triassic. - New Mexico Museum of Natural History and Science Bulletin, 40, pp. 139-168.

Lupe, R., N.J. Silberling 1985: Genetic Relationship between Lower Mesozoic Continental Strata of the Colorado Plateau and Marine Strata of the Western Great Basin: Significance for Accretionary History of Cordilleran Lithotectonic Terranes. - In: Howell, D.G. (Ed.): Tectonostratigraphic Terranes of the Circum-Pacific Region, Circum-Pacific Council for Energy and Mineral Resources. - Earth Science Series, 1, pp. 263-271.

Martini, R., L. Zaninetti, M. Villeneuve, J.-J. Cornée, L. Krystyn, S. Cirilli, P. De Wever, P. Dumitrică, A. Harsolumakso 2000: Triassic pelagic deposits of Timor: paleogeographic and sea-level implications. - Palaeogeography, Palaeoclimatology, Palaeoecology, 160/1-2, pp. 123-151.

Maslo, M. 2008: Taxonomy and stratigraphy of the Upper Triassic heteromorphic ammonoids: preliminary results from Austria. - In: Krystyn, L., G.W. Mandl (Eds): Upper Triassic Subdivisions, Zonations and Events. Abstracts and Excursion-Guide. - Berichte der Geologischen Bundesanstalt, 76, pp. 15-16.

McRoberts, C.A. 2008: Rhaetian bivalves and the Norian/Rhaetian boundary. - In: Krystyn, L., G.W. Mandl (Eds): Upper Triassic Subdivisions, Zonations and Events. Abstracts and ExcursionGuide. - Berichte der Geologischen Bundesanstalt, 76, pp. 41-44.

McRoberts, C.A. 2010: Biochronology of Triassic bivalves. - In: Lucas, S.G. (Ed.): The Triassic Timescale. Geological Society, London, Special Publications, 334, pp. 201-210.

McRoberts, C.A., L. Krystyn, A. Shea 2008: Rhaetian (Late Triassic) Monotis (Bivalvia: Pectinoida) from the eastern Northern Calcareous Alps (Austria) and the end-Norian crisis in pelagic faunas. - Palaeontology, 51/3, pp. 721-735.

McRoberts, C.A., R.B. Blodgett 2000: Late Triassic (Norian) mollusks from the Taylor Mountains Quadrangle, southwestern Alaska. - U.S. Geological Survey Professional Paper 1662, pp. 55-67.

Mojsisovics, Ed. von 1893: Die Cephalopoden der Hallstätter Kalke. - Abhandlungen der kaiserlichköniglichen Geologischen Reichsanstalt, 5, 2, X+835 p. 
Mojsisovics, Ed. von 1902: Die Cephalopoden der Hallstätter Kalke. - Abhandlungen der kaiserlichköniglichen Geologischen Reichsanstalt, 6, I. Abth., Supplement-Heft/24, pp. 175-356.

Monger, J.W.H., H.C. Berg 1987: Lithotectonic terrane map of Western Canada and southeastern Alaska. - U.S. Geological Survey Miscellaneous Field Studies, Map MF-1874-B, 12 pp., 1 sheet, scale 1:2,500,000.

Mostler, H., B. Scheuring, M. Urlichs 1978: Zur Mega-, Mikrofauna und Mikroflora der Kössener Schichten (alpine Obertriass) vom Weißloferbach in Tirol unter besonderer Berücksichtigung der in der suessi- und marshi-Zone auftretenden Conodonten. - In: Zapfe, H. (Ed.): Beiträge zur Biostratigraphie der Tethys-Trias. - Schriftenreihe der Erdwissenschaftlichen Kommissionen, Österreichische Akademie der Wissenschaften, 4, pp. 141-174.

Muller, J.E., B.B. Cameron, K.E. Northcote 1981: Geology and Mineral deposits of Nootka Sound Map-Area (92 E), Vancouver Island, British Columbia. - Geological Survey of Canada, Paper $80-16,53$ p.

Muller, S.W., H.W. Ferguson 1939: Mesozoic stratigraphy of the Hawthorne und Tonopah quadrangles, Nevada. - Geological Society of America Bulletin, 50/10, pp. 1573-1624.

Mutihac, V. 1966: Nouveaux points fossilifères triasiques dans le synclinal du Rarău. - Dări de seamă ale Şedinţelor, Institutul Geologic, 52/1, pp. 291-299. (In Romanian with French summary.)

Mutihac, V. 1968: The geological structure of the northern compartment within the Outer Marginal Syncline of the Eastern Carpathians. Ed. Acad. R. S. Rom., Bucureşti, 127 p. (In Romanian with English summary.)

Muttoni, G., D.V. Kent, F. Jadoul, P.E. Olsen, M. Rigo, M.T. Galli, A. Nicora 2009: Rhaetian magnetobiostratigraphy from the Southern Alps (Italy): Constraints on Triassic chronology. Palaeogeography, Palaeoclimatology, Palaeoecology, 285/1-2, pp. 1-16.

Newton, C.R. 1988: Significance of "Tethyan" Fossils in the American Cordillera. - Science, 242, pp. 385-391.

Nichols, K.M., N.J. Silberling 1979: Early Triassic (Smithian) ammonites of paleoequatorial affinity from the Chulitna terrane, south-central Alaska. - Geological Survey Professional Paper $1121-\mathrm{B}, 5 \mathrm{p}$.

Nokleberg, W.J., L.M. Parfenov, J.W.H. Monger, B.V. Baranov, S.G. Byalobzhesky, TK. Bundtzen, T.D. Feeney, K. Fujita, S.P. Gordey, A. Grantz, A.I. Khanchuk, B.A. Natal'in, L.M. Natapov, I.O. Norton, W.W. Patton, Jr., G. Plafker, D.W. Scholl, S.D. Sokolov, G.M. Sosunov, D.B. Stone, R.W. Tabor, N.V. Tsukanov, T.L. Vallier, K. Wakita 1994: Circum-North Pacific tectono-stratigraphic terrane map. - U.S. Geological Survey Open-File Report 94-714, 2 sheets, scale 1:5,000,000; 2 sheets, scale 1:10,000,000, $211 \mathrm{pp}$.

Nuetzel, A., R.B. Blodgett, G.D. Stanley Jr. 2003: Late Triassic gastropods from the Martin Bridge Formation (Wallowa terrane) of northeastern Oregon and their paleogeographic significance. Neues Jahrbuch für Geologie und Paläontologie, Abhandlungen, 228/1, pp. 83-100.

Ogg, J. G. 2004a: Status of divisions of the International Geologic Time Scale. - Lethaia, 37, pp. 183-199.

Ogg, J. G. 2004a: The Triassic Period. - In: Gradstein, FM., J.G. Ogg, A.G. Smith. (Eds): A Geologic Time Scale 2004. Cambridge University Press, pp. 271-306.

Oravecz, J. 1961: Die Triasbildungen des Schollengebietes zwischen den Gerecse- und Buda-Piliser Gebirgen. - Földtani Közlöny, 91/2, pp.173-186. (In Hungarian with German summary.)

Oravecz, J. 1987: Pilis, Pilisszentlélek, Fekete-hegy - Feketehegy Limestone Member. Magyarország geológiai alapszelvényei (Geological key-sections of Hungary). - Földtani Intézet kiadványa, 4 p. (In Hungarian with English summary.)

Orchard, M.J. 1991: Upper Triassic conodont biochronology and new index species from the Canadian Cordillera. - In: Orchard, M.J., A.D. McCracken (Eds): Ordovician to Triassic Conodont Paleontology of the Canadian Cordillera. - Geological Survey of Canada, Bulletin 417, pp. 299-335. 
Orchard, M.J., E.T. Tozer 1997: Triassic conodont biochronology, its calibration with the ammonoid standard, and a biostatigraphic summary for the Western Canada Sedimentary Basin. Bulletin of Canadian Petroleum Geology, 45/4, pp. 675-692.

Orchard, M.J., E.S. Carter, S.G. Lucas, D.G. Taylor 2007: Rhaetian (Upper Triassic) conodonts and radiolarians. - Albertiana, 35, pp. 59-65.

Pálfy, J., P.L. Smith, J.K. Mortensen, R.M Friedman 1999: Integrated ammonite biochronology and $\mathrm{U}-\mathrm{Pb}$ geochronometry from a basal Jurassic section in Alaska. - Geological Society of America Bulletin, 111/10, pp. 1537-1549.

Parfenov, L.M., G. Badarch, N.A. Berzin, A.I. Khanchuk, M.I. Kuzmin, W.J. Nokleberg, A.V. Prokopiev, M. Ogasawara, H. Yan 2009: Summary of Northeast Asia geodynamics and tectonics. - Stephan Mueller Special Publication Series, 4, pp. 11-33.

Patrulius, D. 1971: Introduction to the Triassic Geology of Romania. - In: Patrulius, D., M. Bleahu, Il. Popescu, S. Bordea (Eds): The Triassic Formations of the Apuseni Mountains and of the East Carpathian Bend. - 2nd Triassic Colloquium Carpatho-Balkan Geological Association, Guidebooks to excursions, Geological Institute, Bucharest, 8, pp. 5-54.

Patrulius, D. 1996: The Triassic and Lower Jurassic Formations of the Transylvanian Nappe System (East Carpathians-Romania). - Memoriile Institutului Geologic al României, 36, pp. 21-30.

Pearson, D.A.B. 1970: Problems of Rhaetian stratigraphy with special reference to the lower boundary of the stage. - The Quarterly Journal of the Geological Society of London, 126/1-2, pp. 125-150.

Popescu, D.A. 2008: Geology and microfacies of Triassic carbonate deposits between Moldova Valley and Trotuş Valley. - Ed. Sedcom Libris, Iaşi, 221 p. (In Romanian.)

Popescu, D.A., L. Popescu 2010: Triassic limestone microfacies and microfosils from the Transylvanian nappes (East Carpathians). Case study of the limestone klippe on the Timon brook, the Rarău Syncline. - Analele Ştiinţifice ale Universităţii "Al. I. Cuza" din Iaşi, Geologie, 56/1, pp. 33-43.

Popov, Yu.N. 1958: Superfamily Clydonitaceae. - In: Luppov, N.P., V.V. Druschitz (Eds): Principles of Paleontology, Mollusks, Cephalopods. 2, Ammonoids. Gosgeoltekhizdat, Moskva, pp. 39-44. (In Russian.)

Prinz, P., A. Hillebrandt von 1994: Stratigraphy and ammonites of ther North Peruvian Pucará Group. - Paleontographica, Abt. A, 233/1-6, pp. 33-42.

Reid, P.A., D.R. Tempelman-Kluit 1987: Upper Triassic Tethyan-type reefs in the Yukon. - Bulletin of Canadian Petroleum Geology, 35/3, pp. 316-332.

Roniewicz, E., G.D. Stanley Jr., 1998: Middle Triassic cnidarians from the New Pass Range, central Nevada. - Journal of Paleontology, 72/2, pp. 246-256.

Roniewicz, E., G.D. Stanley Jr., F. Da Costa Monteiro, J.A. Grant-Mackie 2005: Late Triassic (Carnian) corals from Timor-Leste (East Timor): their identity, setting, and biogeography. - Alcheringa, 29, pp. 287-303.

Sachariewa-Kowatschewa, Kr. 1967: Norische Ammoniten von der Trias bei Kotel. - Annuaire de l'Université de Sofia, Faculté de Géologie et Géographie, Géologie, 60, pp. 75-106. (In Bulgarian with German summary.)

Saleeby, J.B. 1983: Accretionary tectonics of the North American Cordillera. - Annual Review of Earth and Planetary Sciences, 15, p. 45-73.

Sandy, M.R., G.D. Stanley, Jr. 1993: Late Triassic brachiopods from the Luning Formation, Nevada, and their paleobiogeographical significance. - Paleontology, 36/2, pp. 439-480.

Săndulescu, M. 1973: Contributions à la connaissance de la structure géologique du synclinal de Rarău (secteur central). - Dări de seamă ale Şedinţelor, Institutul Geologic, 5. Tectonică şi Geologie regională, 59, pp. 59-92. (In Romanian with French summary.)

Senowbari-Daryan, B., G.D. Stanley Jr. 2009: Taxonomic affinities and paleogeography of Stromatomorpha californica Smith, a distinctive upper Triassic reef-adapted demosponge. Journal of Paleontology, 83/5, pp. 783-793. 
Shevyrev, A.A. 1990: Ammonoids and chronostratigraphy of the Triassic. - Nauka, Moskva, 179 p. (In Russian.)

Shevyrev, A.A. 2001: Class Cephalopoda. - In: Rozanov, A.Yu., A.A. Shevyrev (Eds): Atlas of Triassic invertebrates from Pamir. Nauka, Moskva, pp. 126-150. (In Russian.)

Shevyrev, A.A. 2005: Heteromorph Ammonoids of the Triassic: A Review. - Paleontological Journal, 39/5, pp. 5614-5628.

Silberling, N.J. 1985: Biogeographic significance of the Upper Triassic bivalve Monotis in circumPacific accreted terranes. - In: Howell, D.G. (Ed.): Tectonostratigraphic terranes of the CircumPacific region. - Circum-Pacific Council for Energy and Mineral Resources, Earth Science Series 1, pp. 63-70.

Silberling, N.J. 1990: Allochthonous Terranes of Western Nevada: Current Status. Geology and Ore Deposits of the Great Basin. Great Basin Symposium. - Geological Society of Nevada, GBS, Program with Abstracts, pp. 101-102.

Silberling, N.J., E.T. Tozer 1968: Biostratigraphic Classification of the Marine Triassic in North America. - Geological Society of America, Special Paper 110, 63 p.

Silberling, N.J., R.E. Wallace 1969: Stratigraphy of the Star Peak Group (Triassic) and Overlying Lower Mesozoic Rocks, Humboldt Range, Nevada. - U.S. Geological Survey, Professional Paper $592,50 \mathrm{p}$.

Silberling, N.J., D.L. Jones 1983: Paleontologic evidence for the northward displacement of Mesozoic rocks in accreted terranes of the Western Cordillera. - Geological Association of Canada, Program with Abstracts, 8, p. 62.

Silberling, N.J., K.M. Nichols 1988: Comment on "A defence of the Rhaetian". - Albertiana, 7, pp. 7-8.

Silberling, N.J., D.L. Jones, M.C. Blake, Jr., D.G. Howell 1984: Lithotectonic terrane map of the western conterminous United States. - In: Silberling, N.J., D.L. Jones (Eds): Lithotectonic terrane maps of the North American Cordillera. - U.S. Geological Survey Open-File Report 84-523, Pt. C, 43 p.

Silberling, N.J., D.L. Jones, J.W.H. Monger, P.J. Coney 1992: Lithotectonic terrane map of the North American Cordillera. - U.S. Geological Survey Miscellaneous Investigations Series, Map 1-2176, 2 sheets, scale 1:5,000,000.

Silberling, N.J., J.A. Grant-Mackie, K.M. Nichols 1997: The Late Triassic bivalve Monotis in accreted terranes of Alaska. - U.S. Geological Survey Bulletin, 2151, 21 p.

Smith, J.P. 1927: Upper Triassic marine invertebrate faunas of North America. - U.S. Geol. Survey Professional Paper, 141, 262 p.

Spath, L.F. 1951: The Ammonoidea of the Trias (II). - In: Catalogue of the Fossil Cephalopoda in the British Museum (Natural History), Part V. Adlard and Sons, London, XV+228 p.

Stanley Jr, G.D. 1982: Triassic carbonate development and reefbuilding in Western North America. Geologische Rundschau, 71/3, pp. 1057-1075.

Stanely Jr., G.D. 1994: Early Mesozoic carbonate rocks of the Pucará Group in northern and central Peru. - Paleontographica A, 233/1-6, pp. 1-32.

Stanley Jr., G.D., B. Senowbari-Daryan 1986: Upper Triassic, Dachstein-Type, Reef Limestone from the Wallowa Mountains, Oregon: First Reported Occurrence in the United States. - Palaios, 1, pp. 172-177.

Stanley Jr., G.D., C.M. González-León, M.R. Sandy, B. Senowbari-Daryan, P. Doyle, M. Tamura, D.H. Erwin 1994: Upper Triassic invertebrates from the Antimonio Formation, Sonora, Mexico. - The Paleontological Society, Memoir 36, 33 p.

Stanley Jr., G.D., C.M. González-León 1995: Paleogeographic and tectonic implications of Triassic fossils and strata from the Antimonio Formation, northwestern Sonora. - In: Jacques-Ayala, C., C.M. González-León, J. Roldán-Quintana (Eds): Studies on the Mesozoic of Sonora and Adjacent Areas: Boulder, Colorado. - Geological Society of America, Special Paper, 301, pp. $1-16$. 
Stanley Jr., G.D., B. Senowbari-Daryan 1999: Upper Triassic reef fauna from Quesnel terrane, central British Columbia, Canada. - Journal of Paleontology, 73/5, pp. 787-802.

Stanley Jr., G.D., J.M. Yarnell 2003: New paleontological investigations of Triassic carbonate rocks in the Upper Chulitna district (Chulitna terrane), southcentral Alaska. - In: Clautice, K.H., P.K. Davis (Eds): Short Notes on Alaska Geology 2003. - Division of Geological and Geophysical Surveys Professional Report, 120, pp. 109-116.

Steinmann, G. 1909: Ueber marine Trias in Peru. - Centralblatt für Mineralogie, Geologie und Paläontologie, Jahrgang 1909, pp. 616-619.

Stewart, J.H. 1997: Triassic and Jurassic stratigraphy and paleogeography of west-central Nevada and eastern California. - U. S. Geological Survey, Open-File Report, 97-495, 57 p.

Tatzreiter, F. 1981: Ammonitenfauna und Stratigraphie im höheren Nor (Alaun, Trias) der Tethys aufgrund neuer Untersuchungen in Timor. - Denkschriften Österreichische Akademie der Wissenschaften, Mathematisch-Naturwissenschaftliche Klasse, 121, 142 p.

Taylor, D.G., P.L. Smith, R.A. Laws, J. Guex 1983: The stratigraphy and biofacies trends of the lower Mesozoic Gabbs and Sunrise Formation, west-central Nevada. - Canadian Journal of Earth Sciences, 20/10, pp. 1598-1608.

Tollmann, A. 1976: Analyse des Klassischen Nordalpinen Mesozoicums. - Franz Deutiche, Wien, XV $+580 \mathrm{p}$.

Tozer, E.T. 1958: Stratigraphy of the Lewes River Group (Triassic), Central Laberge Area, Yukon Territory. - Geological Survey of Canada, Bulletin 43, 28 p.

Tozer, E.T. 1963: Illustrations of Canadian Fossils, Triassic of Western and Arctic Canada. - Geological Survey of Canada, Paper 62-19, 27 p.

Tozer, E.T. 1965: Upper Triassic ammonoid zones of the Peace River Foothills, British Columbia, and their bearing on the classification of the Norian Stage. - Canadian Journal of Earth Sciences, 2, pp. 216-226.

Tozer, E.T. 1967: A standard for Triassic time. - Geological Survey of Canada, Bulletin 154, 103 p.

Tozer, E.T. 1970: Marine Triassic Faunas. - In: Biochronology: Standard of Phanerozoic time. Geology and Economic Minerals of Canada, Ch. 11, Economic Geology Report No. 1, 5th ed., pp. 633-640.

Tozer, E.T. 1971: Triassic time and Ammonoids: problems and proposals. - Canadian Journal of Earth Sciences, 8/8, pp. 989-1031.

Tozer, E.T. 1974: Definitions and Limits of Triassic Stages and Substages: Suggestions Prompted by Comparisons Between North America and the Alpine-Mediterranean Region. - In: Die Stratigraphie der alpin-mediterranen Trias, Symposium Wien, Mai 1973. - Schriftenreihe der Erdwissenschaftlichen Kommissionen, Österreichische Akademie der Wissenschaften, 2, pp. 195-206.

Tozer, E.T. 1979: Latest Triassic ammonoid faunas and biochronology, Western Canada. - Current Research, Part B. Geological Survey of Canada, Paper 79-1B, pp. 127-135.

Tozer, E.T. 1980a: Triassic Ammonoidea: Classification, Evolution and Relationship with Permian and Jurassic Forms. - In: House, M.R., J.R. Senior (Eds): - Systematics Association Special Volume No. 18, "The Ammonoidea". Academic Press, London and New York, pp. 66-100.

Tozer, E.T. 1980b: Triassic Ammonoidea: Geographic and Stratigraphic Distribution. - In: House, M.R., J.R. Senior (Eds): - Systematics Association Special Volume No. 18, "The Ammonoidea". Academic Press, London and New York, pp. 397-431.

Tozer, E.T. 1980c: Latest Triassic (Upper Norian) ammonoid and Monotis faunas and correlations. Rivista Italiana di Paleontologia, 85/3-4, pp. 843-876.

Tozer, E.T. 1982a: Marine Triassic Faunas of North America: Their Significance for Assessing Plate and Terrane Movements. - Geologische Rundschau, 71/3, pp. 1077-1104.

Tozer, E.T. 1982b: Late Triassic (Upper Norian) and earliest Jurassic (Hettangian) rocks and ammonoid faunas, Halfway River and Pine Pass map areas, British Columbia. - Current Research, Part B. Geological Survey of Canada, Paper 79-1B, pp. 385-391. 
Tozer, E.T. 1984: The Trias and its Ammonoids: The Evolution of a Time Scale. - Geological Survey of Canada, Miscellaneous Report, 35, 170 p.

Tozer, E.T. 1986: Triassic stage terminology. - Albertiana, 5, pp. 10-14.

Tozer, E.T. 1988: Rhaetian: a substage, not a stage. - Albertiana, pp. 9-15.

Tozer, E.T. 1990: How many Rhaetians? - Albertiana, 8, pp. 10-13.

Tozer, E.T. 1993: Triassic chronostratigraphic divisions considered again. - Albertiana, 11, pp. 32-36.

Tozer, E.T. 1994a: Canadian Triassic Ammonoid Faunas. - Geological Survey of Canada, Bulletin, 467, $663 \mathrm{p}$.

Tozer, E.T. 1994b: Significance of Triassic stage boundaries defined in North America. - Mémoires de Géologie (Lausanne), 22, pp. 155-170.

Turculeț, I. 1971: Recherches géologiques sur les dépôts jurassiques et éocrétacés de la cuvette de Rarău-Breaza. - Studii tehnice şi economice, J/19, 141 p. (In Romanian with French summary.)

Turculeț, I. 1976a: Sur l'âge de calcaires rouges de Ciungi (ruisseau Timon-Rarău) (Carpates Orientales roumaines). - Analele Ştiinţifice ale Universităţii "Al. I. Cuza" din Iaşi, GeologieGeografie, 22, pp. 44-47. (In Romanian with French summary.)

Turculeț, I. 1976b: La faune norienne de la Klippe de Ciungi (Rarău-Bucovine) (Carpates Orientales roumaines). - Anuarul Muzeului de ştiinţe naturale Piatra Neamţ, Geologie-Geografie, 3, pp. 159-163.

Turculeț, I. 1980: La faune norienne de Klippe de Ciungi (Rarău-Bucovine). II. Nautiloidee. Analele Ştiinţifice ale Universităţii "Al. I. Cuza" din Iaşi, Geologie-Geografie, 26, pp. 27-29. (In Romanian with French summary.)

Turculeț, I. 1983: La faune norienne de Klippe de Ciungi (Rarău-Bucovine). III. Ammonoides: Arcestidae, Pinacoceratidea. - Analele Ştiinţifice ale Universităţi "Al. I. Cuza" din Iaşi, Geologie-Geografie, 29, pp. 31-34.

Turculeț, I. 1986: Sur quelques faunes de nautiloïdes neotriasiques de la nappe transylvaine du synclinal de Rarău Breaza (Bucovine). - Studii şi cercetări de geologie, geofizică, geografie, Geologie, 31, pp. 126-137. (In Romanian with French summary.)

Turculeț, I. 2000: Nouvelles données sur la faune d'ammonites noriennes de Ciungi (Rarău) et sur ses valences himalayennes. - Studii şi cercetări de Geologie, 48, pp. 127-148. (In Romanian with French summary.)

Turculeț, I. 2003: Contributions à la connaissance de la faune ammonitique du Sevatien de Rarău et sur ses valences himalayennes. - Analele Ştiinţifice ale Universităţii "Al. I. Cuza" din Iaşi, Geologie, 47, pp. 145-161.

Turculeț, I. 2004: Paleontology of Transylvanian Triassic from Rarău. - Arvin Press, Bucureşti, 170 p. (In Romanian with English summary.)

Turculeț, I. 2005: La faune norienne des klippes de Ciungi (Rarău). IV. Monotidae (Bivalvia). Analele Ştiinţifice ale Universităţii "Al. I. Cuza"din Iaşi, Geologie, 49-50, pp. 161-166.

Urlichs, M. 1972: Ostracoden aus den Kössener Schichten und ihre Abhängigkeit von der Ökologie. - Mitteilungen der Gesellschaft der Geologie- und Bergbaustudenten in Österreich, 21/2, pp. 661-710.

Umhoefer, P.J., H.W. Tipper 1998: Stratigraphy, depositional environment, and tectonic setting of the Upper Triassic to Middle Jurassic rocks of the Chilcotin Ranges, southwestern British Columbia. - Geological Survey of Canada Bulletin, 519, 58 p.

Végh-Neubrandt, E. 1973: Stratigraphische Lage der Triascomplexe des Budaer Gebirge. - Annales Universitatis Scientiarum Budapestinensis de Rolando Eötvös Nominatae, Sectio Geologica, 17, pp. 287-301.

Visscher, H. 1992: The new Triassic stage nomenclature. - Albertiana, 10, pp. 1-2.

Walsh, S.L., F.M. Gradstein, J.G. Ogg 2004: History, philosophy, and application of the Global Stratotype Section and Point (GSSP). - Lethaia, 37, pp. 201-218.

Wang, Y.G., G.E.G. Westermann 1993: Paleoecology of Triassic ammonoids. - Geobios, 26, Suppl. 1, pp. 373-392.

Central European Geology 53, 2010 
Wanner, J. 1910: Neues über die Perm-, Trias- und Juraformation des indoaustralischen Archipels. Centralblatt für Mineralogie, Geologie und Paläontologie, Jahrgang, 1910, pp. 736-741.

Westermann, G.E.G. 1973: The Late Triassic Bivalve Monotis. - In: Hallam, A. (Ed.): Atlas of Paleobiogeography. Elsevier Scientific Publishing Company, Amsterdam, pp. 251-258.

Westermann, G.E.G., H. Verma 1967: The Norian Pine River Bridge Section, British Columbia, and the succession of Monotis. - Journal of Paleontology, 41/3, pp. 798-803.

Wiedmann, J. 1972: Ammoniten-Nuklei aus Schlämmproben der nordalpinen Obertrias - ihre stammesgeschichtliche und stratigraphische Bedeutung. - Mitteilungen der Gesellschaft der Geologie- und Bergbaustudenten, 21/2, pp. 561-622.

Wiedmann, J. 1973: Upper Triassic Heteromorph Ammonites. - In: Hallam, A. (Ed.): Atlas of Paleobiogeography. Elsevier Scientific Publishing Company, Amsterdam, pp. 235-249.

Wiedmann, J. 1974: Zum Problem der Definition und Abgrenzung von Obernor (Sevat) und Rhät. In: Die Stratigraphie der alpin-mediterranen Trias, Symposium Wien, Mai 1973. Schriftenreihe der Erdwissenschaftlichen Kommissionen, Österreichische Akademie der Wissenschaften, 2, pp. 229-235.

Wiedmann, J., F. Fabricius, L. Krystyn, J. Reitner, M. Urlichs 1979: Über Umfang und Stellung des Rhaet. Diskussionsbeitrag zur Sitzung der Internationalen Subkommission für TriasStratigraphie in München, Juli 1978. - Newsletters on Stratigraphy, 8/2, pp. 133-148.

Wignall, P.B., J.-P. Zonneveld, R.J. Newton, K. Amor, M.A. Sephton, S. Hartley 2007: The end Triassic mass extinction record of Williston Lake, British Columbia. - Palaeogeography, Palaeoclimatology, Palaeoecology, 253, pp. 385-406.

Wilson, F.H., R.L. Detterman, J.E. Case 1985: The Alaska Peninsula Terrane: a definition. - U. S. Geological Survey, Open-File Report, 85-450, 17 p.

Yancey, TE., G.D. Stanley Jr., W.E. Piller, M.A. Woods 2005: Biogeography of the Late Triassic wallowaconchid megalodontoid bivalves. - Lethaia, 38, pp. 351-365.

Yarnell, J.M., G.D. Stanley Jr., C.J.R. Hart 1999: New paleontological investigations of Upper Triassic shallow-water reef carbonates (Lewes River Group) in the Whitehorse area, Yukon. - In: Roots, C.F., D.S. Emond (Eds): Exploration and Geological Services Division, Yukon, Indian and Northern Affairs Canada, pp. 179-184.

Zapfe, H. 1962: Untersuchungen im obertriadschen Riff des Gosaukammes (Dachsteingebiet, Oberösterreich). IV. Bisher im Riffkalk des Gosaukammes aufgesammelte Makrofossilien (excl. Riffbildner) und deren stratigraphische Auswertung. - Verhandlungen der Geologischen Bundesanstalt, 2, pp. 346-361.

Zapfe, H. 1965: Beiträge zur Paläontologie der nordalpinen Riffe. Die Fauna der "erratischen Blöcke" auf der Falmbergalm bei Gosau, Oberösterreich (Brachiopoda, Scaphopoda, Gastropoda, Cephalopoda). - Annalen des Naturhistorischen Museum in Wien, 68, pp. 279-308.

Zapfe, H. 1967a: Untersuchungen im obertriadischen Riff des Gosaukammes (Dachsteingebiet, Oberösterreich). VIII. Fragen und Befunde von allgemeiner Bedeutung für die Biostratigraphie der alpine Obertrias. - Verhandlungen der Geologischen Bundesanstalt, 1/2, pp. 13-27.

Zapfe, H. 1967b: Beiträge zur Paläontologie der nordalpinen Riffe. Die fauna der Zlambach-Mergel der Fischerwiese bei Aussee, Steiermark (exkl. Coelenterata und Mikrofossilien). - Annalen des Naturhistorischen Museum in Wien, 71, pp. 413-480.

Zapfe, H. 1974: Trias in Österreich. - Schriftenreihe der Erdwissenschaftlichen Kommissionen, Österreichische Akademie der Wissenschaften, 2, pp. 245-251.

Zapfe, H. 1983: Das Forschungsprojekt "Triassic of the Tethys Realm" (IGCP Proj. 4) Abschlussbericht. - Schriftenreihe der Erdwissenschaftlichen Kommissionen, Österreichische Akademie der Wissenschaften, 5, pp. 7-16.

Zonneveld, J.-P., C.M. Henderson, G.D. Stanley Jr., M.J. Orchard, M.K. Gingras 2007: Oldest scleractinian coral reefs on the North American craton: Upper Triassic (Carnian), northeast British Columbia, Canada. - Palaeogeography, Palaeoclimatology, Palaeoecology, 243, pp. 421-450. 